\title{
Threshold Effects in Online Group Buying
}

\author{
Jiahua Wu, Mengze Shi, Ming $\mathrm{Hu}$ \\ Rotman School of Management, University of Toronto, Toronto, Ontario, Canada M5S 3E6 \\ \{jiahua.wu09@rotman.utoronto.ca,mshi@rotman.utoronto.ca,ming.hu@rotman.utoronto.ca\}
}

\begin{abstract}
This paper studies two types of threshold-induced effects: a surge of new sign-ups around the time when the thresholds of group-buying deals are reached, and a stronger positive relation between the number of new sign-ups and the cumulative number of sign-ups before the thresholds are reached than afterwards. This empirical study uses a dataset that records the inter-temporal cumulative number of sign-ups for groupbuying deals in 86 city markets covered by Groupon, during a period of 71 days when Groupon predominantly used "a deal a day" format for each local market and posted the number of sign-ups in real time. We find that the first type of threshold effects is significant in all product categories and in all markets. The second type of threshold effects varies across product categories and markets. Our results underscore the importance of considering product and market characteristics in threshold design decisions for online group buying.
\end{abstract}

Key words: Threshold effects; Group buying

\section{Introduction}

Online group-buying industry has witnessed phenomenal growth since the début of Groupon in 2008 (Pepitone 2011). Most group-buying websites were created to facilitate the coordination among a group of interested buyers to achieve their common purchase goals often in the form of price discounts. The discounts will not be available until the total number of committed purchases exceeds a pre-specified deal threshold. Determinants of such purchase thresholds may vary across the deals. For instance, while the threshold for a wine deal can be based on the supplier's inventory and acquisition costs, the threshold for a restaurant deal is likely to depend on the restaurant's cost structure, capacity, and business model.

In this paper, taking the presence of deal thresholds as given, we empirically investigate the effect of thresholds on consumer's sign-up behavior. Our investigation utilizes a dataset collected from Groupon.com, during a time period when the company predominantly used "a deal a day" format for each local market. For each Groupon deal, deal characteristics, threshold level, and real-time 
updated number of sign-ups were posted on the website. These data provide us with an opportunity to infer the effects of thresholds from the sign-up patterns over time. Our study finds two types of threshold-induced behavior. The first type of threshold effects refers to a substantial increase in the number of sign-ups around the time when the threshold is reached. Our results show that this effect is significant in all product categories and in all markets. The second threshold effect refers to a stronger positive relation between the number of new sign-ups and cumulative number of sign-ups before the thresholds are met than afterwards. When comparing across many product categories, we find the latter effect to be stronger for the category consisting of non-American food restaurants. When comparing across cities, we find the latter effect to be stronger among largest cities and those cities located in the Northeast region of the United States.

Our paper is related to the growing analytical literature on group buying as a selling mechanism. In the presence of demand uncertainty, the group-buying mechanism is shown to outperform posted pricing under demand heterogeneity, economies of scale (Anand and Aron 2003), and risk-seeking sellers (Chen et al. 2007). Group buying can also be used as a mechanism for price discrimination and advertising (Edelman et al. 2010). Jing and Xie (2011) examine the use of group-buying mechanism in facilitating social interactions. Their analysis shows that group buying dominates referral program when interpersonal communication is very efficient or when the less-informed consumers have high product valuation. Hu et al. (2013) investigate the benefit of revealing the cumulative number of sign-ups in increasing deal success rates. Revealing the sign-up information can reduce consumer's reluctance to sign up to deals for fear that the deals fail in reaching the thresholds.

A few researchers have also empirically studied the group-buying industry. Dholakia (2010) investigates the profitability of Groupon promotions via a survey of 150 businesses that had run Groupon promotions, and finds that promotion was profitable for about two-thirds of the respondents. Byers et al. (2012) collect data from Groupon and LivingSocial to investigate the relation between total sales and deal characteristics. They also couple the daily deal dataset with an additional dataset from Facebook, and provide evidence that significant word of mouth took place 
during the lifetime of daily deals. Similarly, Li and Wu (2012) explore the impacts of observational learning and word of mouth on facilitating sales of daily deals on Groupon. Finally, our paper is closely related to Zhang and Liu (2012), who investigate the observational learning behavior in the microloan market. Lenders in the microloan market needed to cooperate with each other in order to reach the full amount requested by the borrower. Unlike the above papers, our research focuses on the thresholds as a mechanism and examines the effects of thresholds on stimulating the interest in signing up to group-buying deals.

\section{Background and Data \\ 2.1. Industry Background}

Group-buying firms are third-party intermediaries that facilitate the coordination between a large group of consumers. Such coordination permits consumers to collectively enjoy the quantity discounts offered by the sellers. Online group-buying firms first emerged in the late 1990s to reach geographically dispersed consumers through Internet. They offered attractive deals, often in the form of deep discounts for durable goods such as cameras; these deals would be on if and only if a pre-determined number of consumers would sign up within a pre-determined time period. Most

leading players including Mercata and Mobshop ceased their operations after a few years (Kauffman and Wang 2002). However, starting from 2008, led by Groupon, the online group-buying industry resurrected. The new generation of group-buying firms offered "a deal a day" at each city market to local consumers. When a deal was on, the group-buying firm typically kept half of the revenue during the time period when our data was collected.

The online group-buying industry has experienced remarkable growth in the last few years. Groupon, since its début in 2008, increased its total number of subscribers to over 200 million as of March 2013. Groupon extended its coverage to more than 500 markets in 48 countries, up from just 28 U.S. markets in 2009. Meantime, the company's phenomenal success had quickly attracted a large number of competitors entering the market. Currently, there are approximately 500 websites offering similar group-buying services, but only LivingSocial had emerged as a genuine competitor. By November 2012, Groupon commanded about 50 to 55 percent of the industry's market share, 
where the market share of No. 2 site LivingSocial was around 20 to 25 percent. To meet the needs of vendors and fend off the competition from other group-buying websites, Groupon started offering multiple deals a day, some with longer sign-up periods (Fowler 2010). Our data was collected before this move. During the data collection period, Groupon predominantly operated under "a deal a day" format.

\subsection{Data}

We hired a research assistant at a major university to build a data crawler on the Google App Engine platform. The data crawler extracted deal information, such as deal description, deal price, discount level, and threshold, whenever a new deal was posted. The program updated the cumulative number of sign-ups with the interval of every five minutes. We use this real-time dataset to keep track of consumers' responses to various group buying deals during the lifetime of each deal, and to uncover the patterns of sign-up accumulation.

Table 1 Summary Statistics of All Deals.

\begin{tabular}{lrrrr}
\hline & Mean & Std. Dev. & Minimum & Maximum \\
\cline { 2 - 4 } Deal Attributes & & & 2 & 250 \\
Deal Price (\$) & 30.68 & 30.53 & 9.96 & 800 \\
Discount Level (\%) & 56.35 & 68.50 & 56 & 8,364 \\
Threshold & 55.40 & $1,332.94$ & 56 \\
Market Population (thousands) & 854.30 & & 5 \\
Outcome & & & 29,380 \\
Total Amount Purchased & 784.80 & $1,331.57$ & \\
\hline
\end{tabular}

Note: Deal Price denotes the net price a consumer needed to pay if the deal tips. Discount Level denotes the markdown of deal price relative to the regular price. Threshold denotes the minimum number of committed purchases for the deal to succeed. Market Population is the population of the local market where the deal was posted. Total Amount Purchased denotes the number of consumers who purchased the product or service by the end of the sign-up process.

We focus on the market leader Groupon. Our data includes a total of 4,208 deals from 86 cities or regions covered by Groupon between September 28th, 2010 and December 07th, 2010. The duration of the observation period was 71 days in total. For each deal, we recorded a set of deal attributes and monitored the inter-temporal sign-up process. Table 1 presents the summary statistics for all 
these 4,208 deals. The average deal price in the sample was $\$ 30.68$, with an average discount level of $56 \%$ off. Each of these deals contained a threshold of sign-up numbers for the deal to succeed. A group-buying deal would be off if the total number of committed consumers did not reach the threshold. The average threshold value specified by Groupon was around 55. The average number of coupons purchased for each deal was around 785. Thus, the average revenue for a typical deal was $\$ 24,084$, which would be shared 50-50 between vendors and Groupon. In our sample, all deals reached the thresholds before expiration.

We divide all the deals into 17 different product and service categories based on deal descriptions by consulting the popular online deal aggregators such as dealradar.com. The definition of each category is given in Table 2. Most of them were service categories, except for Clothing $\&$ Accessories and Other Physical Products which consisted of physical goods exclusively. We manually linked all the deals to the categories. The distribution of deals across categories is summarized in Table 3. The most popular category was Beauty $\mathscr{E}$ Spas, accounting for over $15 \%$ of deals in the sample. Table 3 also shows the summary statistics of deal thresholds and total amounts purchased for each category. There were considerable variations in threshold size and purchase amount both within and across categories. On average, the food categories, including Fast Food, American Food and Other Food, had very high thresholds and large numbers of purchases. Finally, the Clothing $\mathscr{G}$ Accessories category had 1,639 sign-ups per deal, the highest for a single category.

We supplemented the deal data with geographic information, namely market population and the geographic region where the market is located. We summarize the location statistics in Tables 4 and 5. City population statistics were collected from U.S. census bureau. In all the markets where Groupon operated, the average market size was around 0.85 million. We also divided these markets into five regions according to their geographic locations, namely, West, Midwest, South, Northeast and Canada. The definition of four regions within U.S. follows the same approach adopted by U.S. census bureau. The majority of the markets, around $94.2 \%$, were within U.S., and the rest $5.8 \%$ spreading over Canada. Within U.S., Groupon was most active in the South region, operating in 29 markets. Groupon operated in the least number of markets in the Northeast region, with only 
Table 2 Description of Deal Categories.

\begin{tabular}{ll}
\hline Category & Description \\
\hline Arts \& Entertainment & Symphony, concert, ballet, etc. \\
Sports \& Recreation & Sports games (golf, basketball, bowling, football) and outdoor activities \\
Beauty \& Spas & Spa, manicure, facial treatment, hair service, skin care \\
Fitness \& Nutrition & Gym or fitness center membership, yoga, etc. \\
Photography \& Photo Services & Photography class, photo session, photo or video digitalization, photo books \\
Travel \& Hospitality & Travelling related services, such as transportation and hotel \\
Kids \& Pets & Service and products for kids or pets \\
Automotive & Auto detailing, oil and filter replacement, vehicle inspection, etc. \\
Classes \& Workshops & Dance, wine, painting, flight classes \\
Dental & Teeth whitening, dental cleaning, etc. \\
Health \& Medical & Medical exam, x-ray, chiropractic, etc. \\
Clothing \& Accessories & Clothing, accessories, shoes, etc. \\
Home Products \& Services & House cleaning, floor installation and furniture \\
Fast Food & Pizza, burger, sandwich, pastry, popcorn, etc. \\
American Food & Pub, bar, steakhouse, etc. \\
Other Food & Italian, French, Chinese, Japanese food or home-delivered food \\
Other Physical Products & Wine, book, personalized paper products, fine art prints, etc. \\
\hline
\end{tabular}

Table 3 Distribution of Deals across Categories.

\begin{tabular}{|c|c|c|c|c|c|c|}
\hline & \multicolumn{2}{|c|}{ Observations } & \multicolumn{2}{|c|}{ Threshold } & \multicolumn{2}{|c|}{ Total Amount Purchased } \\
\hline & Count & $\%$ & Mean & Std. Dev. & Mean & Std. Dev. \\
\hline Arts \& Entertainment & 340 & $8.08 \%$ & 49.66 & 52.98 & 882 & 1,722 \\
\hline Sports \& Recreation & 468 & $11.12 \%$ & 53.40 & 56.54 & 849 & 1,252 \\
\hline Beauty \& Spas & 660 & $15.68 \%$ & 54.17 & 65.30 & 637 & 972 \\
\hline Fitness \& Nutrition & 192 & $4.56 \%$ & 41.69 & 52.32 & 426 & 505 \\
\hline Photography \& Photo Services & 239 & $5.68 \%$ & 38.10 & 46.01 & 564 & 662 \\
\hline Travel \& Hospitality & 41 & $0.97 \%$ & 43.41 & 40.95 & 372 & 374 \\
\hline Kids \& Pets & 52 & $1.24 \%$ & 57.21 & 93.24 & 708 & 943 \\
\hline Automotive & 76 & $1.81 \%$ & 64.93 & 92.67 & 1,119 & 1,508 \\
\hline Classes \& Workshops & 166 & $3.94 \%$ & 42.08 & 50.21 & 580 & 1,334 \\
\hline Dental & 76 & $1.81 \%$ & 40.20 & 44.90 & 345 & 456 \\
\hline Health \& Medical & 85 & $2.02 \%$ & 42.41 & 42.58 & 490 & 491 \\
\hline Clothing \& Accessories & 178 & $4.23 \%$ & 53.96 & 68.22 & 1,639 & 3,742 \\
\hline Home Products \& Services & 115 & $2.73 \%$ & 40.57 & 39.76 & 471 & 467 \\
\hline Fast Food & 382 & $9.08 \%$ & 63.77 & 83.61 & 1,041 & 1,388 \\
\hline American Food & 314 & $7.46 \%$ & 92.04 & 97.41 & 1,071 & 902 \\
\hline Other Food & 403 & $9.58 \%$ & 79.02 & 91.84 & 988 & 1,008 \\
\hline Other Physical Products & 421 & $10.00 \%$ & 37.24 & 35.24 & 450 & 576 \\
\hline
\end{tabular}


12 markets. The number of markets within the other two regions were similar, with 19 markets in the West region and 21 markets in the Midwest region. At the deal level, the distribution of deals across different regions is consistent with the distribution of cities across regions, because deals were typically offered daily in each market.

Table 4 Distribution of Deals by Market Populations.

\begin{tabular}{|c|c|c|c|c|c|c|}
\hline & \multicolumn{2}{|c|}{ Observations } & \multicolumn{2}{|c|}{ Threshold } & \multicolumn{2}{|c|}{ Total Amount Purchased } \\
\hline & Count & $\%$ & Mean & Std. Dev. & Mean & Std. Dev. \\
\hline$<0.25 \mathrm{mil}$ & 988 & $23.50 \%$ & 30.92 & 29.21 & 467.9 & 724.4 \\
\hline $0.25-0.5 \mathrm{mil}$ & 972 & $23.10 \%$ & 38.42 & 35.48 & 553.9 & 685.9 \\
\hline $0.5-1 \mathrm{mil}$ & 1,562 & $37.12 \%$ & 59.64 & 62.92 & 944.0 & $1,496.0$ \\
\hline$>1 \mathrm{mil}$ & 686 & $16.30 \%$ & 105.05 & 114.00 & 1206.0 & $1,977.5$ \\
\hline
\end{tabular}

Table 5 Distribution of Deals across Geographic Regions.

\begin{tabular}{|c|c|c|c|c|c|c|}
\hline & \multicolumn{2}{|c|}{ Observations } & \multicolumn{2}{|c|}{ Threshold } & \multicolumn{2}{|c|}{ Total Amount Purchased } \\
\hline & Count & $\%$ & Mean & Std. Dev. & Mean & Std. Dev. \\
\hline West & 953 & $22.65 \%$ & 60.03 & 56.58 & 949.8 & 1,742 \\
\hline Midwest & 962 & $22.86 \%$ & 56.68 & 83.64 & 744.0 & 1,115 \\
\hline South & 1,401 & $33.29 \%$ & 54.81 & 66.33 & 755.7 & 1,306 \\
\hline Northeast & 634 & $15.07 \%$ & 54.48 & 74.56 & 667.3 & 1,131 \\
\hline Canada & 258 & $6.13 \%$ & 38.93 & 27.72 & 773.9 & 734 \\
\hline
\end{tabular}

During our data-collection period, deals were posted daily for a duration of 24 hours from Mondays to Thursdays. However, duration of deals posted on Fridays and weekends could vary from 24 hours to 72 hours. In some relatively small markets, Groupon would post 72-hour deals on Friday. We also saw a transition from 72-hour deals to 48-hour deals during our data-collection period.

\section{Threshold Effects on Sign-Up Behavior 3.1. Preliminary Evidence}

The main objective of this paper is to investigate the effects of thresholds on the rate of signing up to the deals. To derive some intuition on potential threshold effects, we first examine the raw data, and seek to find out if there exists any consistent sign-up pattern around the times when thresholds were reached. Since the deals were tipped at different time points of a day, for each deal 
we re-align the time periods in data by the time period when the threshold was reached. With the re-aligned data, time 0 is the period when all deals reached their thresholds. We plot the average sign-up pattern across all deals during the one-and-a-half-hour (90 minutes) time window before and after the threshold was reached (see Figure 1). In particular, the curve in Figure 1(a) shows the average number of sign-ups every 5 minutes. We also compute the ratio between the number of new sign-ups during the current time interval and the cumulative number of sign-ups at the end of the previous time interval, and plot the ratio over time in Figure 1(b).

\section{Figure 1 Sign-Up Pattern during the One-and-a-half-hour Time Window before and after the Threshold was} Reached.

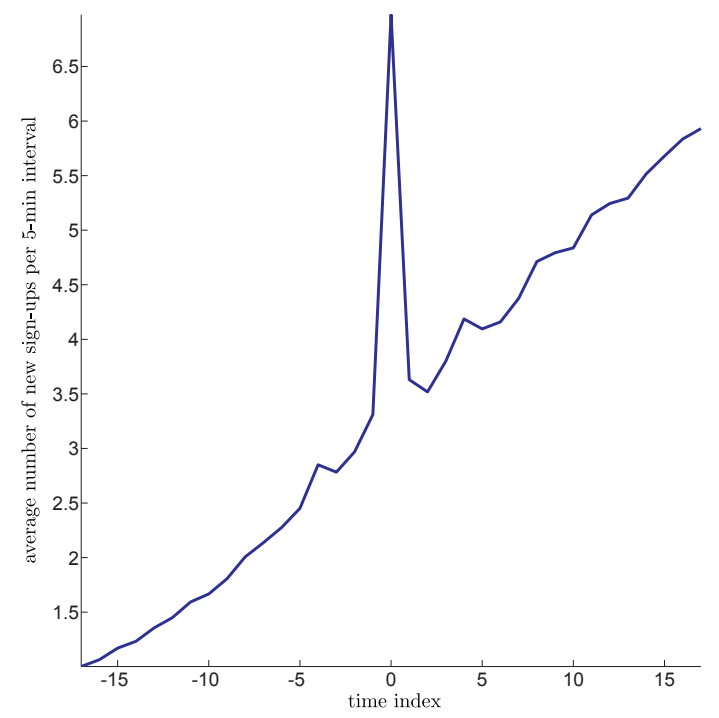

(a)

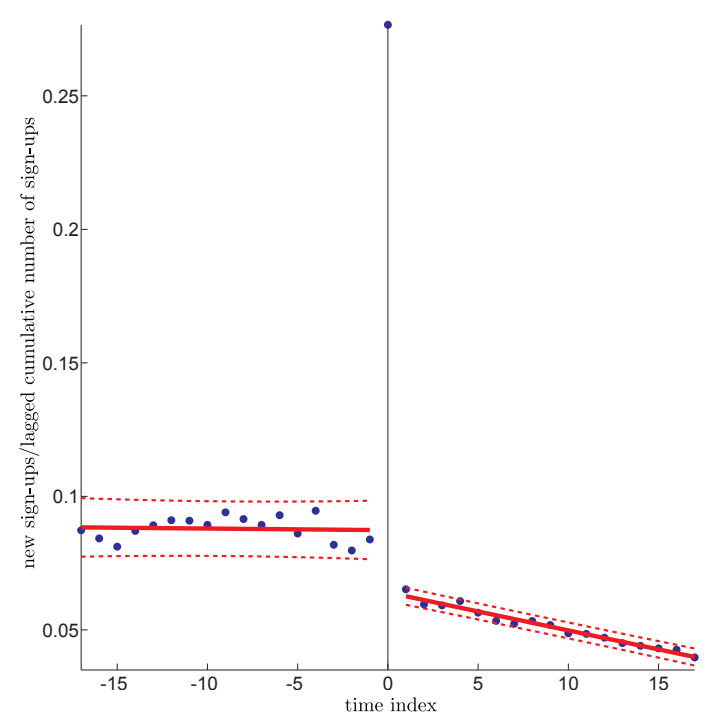

(b)

Note. The x-axis indicates the time index. The y-axis in figure (a) denotes the average number of new sign-ups during each 5-minute time interval. In figure (b), the y-axis denotes the ratio between the number of new sign-ups during a time interval and the cumulative number of sign-ups up to the end of the previous time interval, solid lines are fitted values from $1^{\text {st }}$ order polynomial regressions on either side of the time interval when threshold was reached, and dotted lines are $95 \%$ confidence intervals.

The figures suggest two interesting patterns around the time when the thresholds were reached. First, Figure 1(a) shows a spike during the time interval when the thresholds were reached. In other words, the number of sign-ups during the periods when thresholds were reached is substantially higher than that during the time periods right before or right after it. Second, Figure 1(b) shows a significant level shift in the ratio before and after the thresholds were reached: the ratio stays 
stable before the thresholds were reached, but shifts downwards right after the thresholds were reached and maintains a downward trend afterwards.

\subsection{Empirical Model}

The preliminary evidence from the data indicates that the thresholds may indeed affect consumers' sign-up behavior. However, many confounding factors, such as varying online traffic to the websites at different times of the day and unobserved deal heterogeneity, may contribute to the sign-up pattern observed in Figure 1. In this section, we seek to more rigorously establish the threshold effects through formal statistical analyses.

3.2.1. The Base Model. We start our analysis with a flexible model specification to distill the sign-up pattern around the thresholds. We include a series of time dummy variables, with each variable capturing the sign-up pattern during a 5-minute time interval around the time period when the threshold was reached. The dependent variable in our model, denoted by $y_{i, t}$, is the number of new sign-ups during the $t^{\text {th }}$ time interval for deal $i$. In order to control the unobserved deal heterogeneity, we apply a deal-fixed effect model with the following specification:

$$
y_{i, t}=\sum_{j=-T}^{T} \alpha_{j} I_{\left\{s_{i, t}=j\right\}}+\psi_{t}+\mu_{i}+\epsilon_{i, t},
$$

where $t$ represents the time index before re-aligning the deals, and $s_{i, t}$ indicates the time index after re-aligning the deals at the time period when the threshold was reached. Recall that with the re-aligned data, time 0 is the period when a deal reaches its threshold. Consequently, $s_{i, t}$ is equal to 0 if deal $i$ reaches its threshold at time period $t$. Similarly, $s_{i, t}=j$ for all $j>0$ (resp., $j<0$ ) represents that time period $t$ is the $j^{\text {th }}$ period after (resp., before) deal $i$ reaches its threshold, and $I_{\left\{s_{i, t}=j\right\}}$ for all $j$ is a dummy variable which is equal to 1 if $s_{i, t}=j$, and zero otherwise. The set of time dummy variables, $I_{\left\{s_{i, t}=j\right\}}, j=-T, \ldots, T$, is used to capture the sign-up pattern around the time when the thresholds are reached, where $T$ reflects the width of the time window. In addition, $\psi_{t}$ measures the time-of-the-day fixed effect using 5 -minute time dummy, and $\mu_{i}$ measures the deal fixed effects. The term $\epsilon_{i, t}$ is the error component. 
To estimate the base model, we can apply standard approaches for estimating fixed-effects panel models. The fixed effects can be eliminated by either taking differences between adjacent observations from the same deal or subtracting the average over time from every variable, i.e., timedemeaning. Then, we can apply the generalized least squared (GLS) estimator to the transformed data.

3.2.2. The Extended Model with Lagged Variables. Though the base model allows us to capture the sign-up pattern around thresholds in a flexible way, it does not reflect the dependency of the new sign-ups on the cumulative number of sign-ups as suggested by Figure 1(b). Consequently, we extend the base model by introducing the lagged cumulative sign-ups, $Y_{i, t-1}$, into the model. The extended model can be formulated as follows:

$$
y_{i, t}=\sum_{j=-T}^{T} \alpha_{j} I_{\left\{s_{i, t}=j\right\}}+\sum_{j=-T}^{T} \beta_{j} I_{\left\{s_{i, t}=j\right\}} Y_{i, t-1}+\psi_{t}+\mu_{i}+\epsilon_{i, t} .
$$

Similar to the base model, we include the interactions between time dummies after re-alignment, $I_{\left\{s_{i, t}=j\right\}}$, and the lagged cumulative number of sign-ups, $Y_{i, t-1}$, to capture the relation between the new sign-ups and the cumulative number of sign-ups in a flexible way.

However, unlike the base model which can be estimated consistently using GLS estimator, the estimation of a fixed effects model with lagged variables is more technically involved. The lagged regressor is likely to be correlated with the fixed effects, which gives rise to "dynamic panel bias" (Nickell 1981). To solve this problem, we apply the generalized method of moments (GMM) approach proposed by Arellano and Bond (1991). First, we take difference of Equation (2) to eliminate the deal fixed effects:

$$
\begin{aligned}
y_{i, t}-y_{i, t-1}= & \sum_{j=-T}^{T} \alpha_{j}\left(I_{\left\{s_{i, t}=j\right\}}-I_{\left\{s_{i, t-1}=j\right\}}\right)+\sum_{j=-T}^{T} \beta_{j}\left(I_{\left\{s_{i, t}=j\right\}} Y_{i, t-1}-I_{\left\{s_{i, t-1}=j\right\}} Y_{i, t-2}\right) \\
& +\left(\psi_{t}-\psi_{t-1}\right)+\left(\epsilon_{i, t}-\epsilon_{i, t-1}\right) .
\end{aligned}
$$

As $Y_{i, t-1}$ is correlated with the error term, specifically $\epsilon_{i, t-1}$, GLS yields inconsistent estimates after the first-difference transformation. However, if there is no serial correlation in the error term $\epsilon_{i, t}$, 
then the longer lags of the regressors, i.e., $Y_{i, k}, k=t-2, \ldots, 1$, which are correlated with $y_{i, t-1}$ (see Equation (2)), and thus $Y_{i, t-1}$, but not with the error term $\epsilon_{i, t-1}$, can serve as instruments for the model after the first-difference transformation. In the case of our model, $Y_{i, t-2}$, and $I_{\left\{s_{i, t-1}=j\right\}} Y_{i, t-2}$, together with their longer lags can serve as GMM instruments for Equation (3). The differences of the strictly exogenous variables, i.e., $I_{\left\{s_{i, t-1}=j\right\}}$ and $\psi_{t}$, can serve as standard instruments.

We capture the unobserved heterogeneity across deals with deal fixed effects. The observed deal variations as described by product/service categories, deal prices and discounts, and city characteristics are unlikely to capture all sources of deal heterogeneities. For example, restaurants within a city can have different locations, offer different cuisines, and enjoy different reputations. For Equation (2) to identify threshold effects on group-buying deals, we implicitly assume that unobserved deal attributes are accounted for by a time-invariant component, i.e., $\mu_{i}$. This fixed component controls for unobserved deal attributes, which may positively correlate with both lagged cumulative number of sign-ups, $Y_{i, t-1}$, and the number of new sign-ups, $y_{i, t}$, and thus solves an "errors in variables" type of endogeneity problem (Villas-Boas and Winer 1999). Given the panel data structure, we are able to use deal-specific fixed effects to control the variations across deals.

\subsection{Results}

We next present the empirical results for the base model and the extended model. Our analysis uses an one-and-a-half-hour time window before and after the threshold was reached for regression analysis, i.e., $T=17$. The usage of a relatively small time window around the time when thresholds were reached eliminates other unrelated factors, and allows us to focus on the effects of thresholds on consumers' sign-up behavior.

Since the earliest observation serves as the reference level, we have a total of 34 5-minute time dummy variables, i.e., $I_{\left\{s_{i, t}=j\right\}}, j=-16, \ldots, 17$, to capture the sign-up pattern around thresholds. To focus on the main findings, we do not interact every single time dummy variable with the lagged cumulative number of sign-ups. Instead, we divide the three-hour time window into four non-overlapping time periods of equal length, create four new time dummies, with each representing a 45-minute time interval, and interact the newly created time dummies with the lagged 
cumulative number of sign-ups. The interaction terms between these four time dummies and the lagged cumulative number of sign-ups are sufficient to capture the level shift in the ratio between new sign-ups and the cumulative number of sign-ups when the thresholds were passed, as well as the trend of the ratio both before and after reaching the thresholds.

Table 6 Regression Results of the Base Model using Three-hour Data.

\begin{tabular}{cccccccccccc}
\hline & Estimates & & Estimates & & Estimates & & Estimates & & Estimates & Estimates \\
\hline$\alpha_{-16}$ & $-0.094^{* *}$ & $\alpha_{-10}$ & $-0.437^{* * *}$ & $\alpha_{-4}$ & -0.076 & $\alpha_{1}$ & 0.131 & $\alpha_{7}$ & $0.355^{* *}$ & $\alpha_{13}$ & $0.953^{* * *}$ \\
& $(0.037)$ & & $(0.063)$ & & $(0.101)$ & & $(0.185)$ & & $(0.178)$ & $(0.212)$ \\
& $-0.152^{* * *}$ & $\alpha_{-9}$ & $-0.447^{* * *}$ & $\alpha_{-3}$ & $-0.266^{* *}$ & $\alpha_{2}$ & -0.085 & $\alpha_{8}$ & $0.623^{* * *}$ & $\alpha_{14}$ & $1.140^{* * *}$ \\
$\alpha_{-15}$ & $(0.041)$ & & $(0.067)$ & & $(0.106)$ & & $(0.152)$ & & $(0.193)$ & $(0.232)$ \\
& $-0.257^{* * *}$ & $\alpha_{-8}$ & $-0.385^{* * *}$ & $\alpha_{-2}$ & $-0.198^{*}$ & $\alpha_{3}$ & 0.104 & $\alpha_{9}$ & $0.642^{* * *}$ & $\alpha_{15}$ & $1.277^{* * *}$ \\
$\alpha_{-14}$ & $(0.043)$ & & $(0.074)$ & & $(0.112)$ & & $(0.150)$ & & $(0.187)$ & $(0.237)$ \\
& $-0.288^{* * *}$ & $\alpha_{-7}$ & $-0.396^{* * *}$ & $\alpha_{-1}$ & 0.023 & $\alpha_{4}$ & $0.400^{* *}$ & $\alpha_{10}$ & $0.634^{* * *}$ & $\alpha_{16}$ & $1.403^{* * *}$ \\
$\alpha_{-13}$ & $(0.051)$ & & $(0.080)$ & & $(0.130)$ & & $(0.161)$ & & $(0.198)$ & $(0.252)$ \\
& $-0.351^{* * *}$ & $\alpha_{-6}$ & $-0.394^{* * *}$ & $\alpha_{0}$ & $3.582^{* * *}$ & $\alpha_{5}$ & 0.223 & $\alpha_{11}$ & $0.881^{* * *}$ & $\alpha_{17}$ & $1.477^{* * *}$ \\
$\alpha_{-12}$ & $(0.052)$ & & $(0.087)$ & & $(0.315)$ & & $(0.156)$ & & $(0.216)$ & $(0.296)$ \\
& $-0.357^{* * *}$ & $\alpha_{-5}$ & $-0.347^{* * *}$ & & & $\alpha_{6}$ & 0.211 & $\alpha_{12}$ & $0.942^{* * *}$ & & \\
$\alpha_{-11}$ & $(0.058)$ & & $(0.094)$ & & & & $(0.181)$ & & $(0.212)$ & &
\end{tabular}

Time-of-the-day fixed effects

Deal fixed effects

Number of observations

Number of deals

Adjusted R-squared

Yes
Yes
147,112
4,208
0.026

Yes

, 208

Note: Dependent variable is the number of new sign-ups per 5-min time interval. Standard errors are clustered by deal and reported in parentheses. ${ }^{* * *} p<0.01,{ }^{* *} p<0.05,{ }^{*} p<0.1$.

Table 6 shows the regression result of our base model. The coefficient of the time dummy when the thresholds were reached $\left(\hat{\alpha}_{0}=3.582, p<0.01\right)$ is significantly greater than the coefficients of other time dummies. We also visualize the estimated coefficients by plotting the estimates and their corresponding 95\% confidence intervals in Figure 2(a). Similar to Figure 1(a) created from the raw data, we observe a clear spike in the number of sign-ups during the time interval when the thresholds were reached even if we control for heterogeneous time traffic and unobserved deal heterogeneity. This verifies the first-type of threshold effects: a surge in the number of new sign-ups around the time when threshold was reached. 
Table 7 Regression Results of the Extended Model using Three-hour Data.

\begin{tabular}{|c|c|c|c|c|c|c|c|c|c|}
\hline & GLS & GMM(2 lags) & GMM(3 lags) & GMM(4 lags) & & GLS & GMM(2 lags) & GMM(3 lags) & GMM(4 lags) \\
\hline$\alpha_{-16}$ & $\begin{array}{r}-0.069^{*} \\
(0.037)\end{array}$ & $\begin{array}{c}-0.115^{* * *} \\
(0.044)\end{array}$ & $\begin{array}{c}-0.123^{* * *} \\
(0.044)\end{array}$ & $\begin{array}{c}-0.126^{* * *} \\
(0.044)\end{array}$ & $\alpha_{1}$ & $\begin{array}{c}-0.172 \\
(0.174)\end{array}$ & $\begin{array}{c}-1.044^{*} \\
(0.536)\end{array}$ & $\begin{array}{c}-1.029^{*} \\
(0.550)\end{array}$ & $\begin{array}{r}-0.920 \\
(0.609)\end{array}$ \\
\hline$\alpha_{-15}$ & $\begin{array}{c}-0.101^{* *} \\
(0.040)\end{array}$ & $\begin{array}{c}-0.196^{* * *} \\
(0.063)\end{array}$ & $\begin{array}{c}-0.213^{* * *} \\
(0.063)\end{array}$ & $\begin{array}{c}-0.220^{* * *} \\
(0.064)\end{array}$ & $\alpha_{2}$ & $\begin{array}{c}-0.473^{* *} \\
(0.188)\end{array}$ & $\begin{array}{c}-1.403^{* *} \\
(0.610)\end{array}$ & $\begin{array}{c}-1.377^{* *} \\
(0.624)\end{array}$ & $\begin{array}{c}-1.265^{*} \\
(0.681)\end{array}$ \\
\hline$\alpha_{-14}$ & $\begin{array}{c}-0.183^{* * *} \\
(0.042)\end{array}$ & $\begin{array}{c}-0.329^{* * *} \\
(0.083)\end{array}$ & $\begin{array}{c}-0.354^{* * *} \\
(0.083)\end{array}$ & $\begin{array}{c}-0.365^{* * *} \\
(0.084)\end{array}$ & $\alpha_{3}$ & $\begin{array}{r}-0.366^{*} \\
(0.204)\end{array}$ & $\begin{array}{c}-1.346^{* *} \\
(0.619)\end{array}$ & $\begin{array}{c}-1.309^{* *} \\
(0.633)\end{array}$ & $\begin{array}{r}-1.193^{*} \\
(0.698)\end{array}$ \\
\hline$\alpha_{-13}$ & $\begin{array}{c}-0.195^{* * *} \\
(0.049)\end{array}$ & $\begin{array}{c}-0.391^{* * *} \\
(0.104)\end{array}$ & $\begin{array}{c}-0.424^{* * *} \\
(0.103)\end{array}$ & $\begin{array}{c}-0.438^{* * *} \\
(0.105)\end{array}$ & $\alpha_{4}$ & $\begin{array}{r}-0.166 \\
(0.212)\end{array}$ & $\begin{array}{r}-1.202^{*} \\
(0.632)\end{array}$ & $\begin{array}{r}-1.153^{*} \\
(0.647)\end{array}$ & $\begin{array}{c}-1.034 \\
(0.710)\end{array}$ \\
\hline$\alpha_{-12}$ & $\begin{array}{c}-0.245^{* * *} \\
(0.053)\end{array}$ & $\begin{array}{c}-0.489^{* * *} \\
(0.123)\end{array}$ & $\begin{array}{c}-0.528^{* * *} \\
(0.121)\end{array}$ & $\begin{array}{c}-0.546^{* * *} \\
(0.123)\end{array}$ & $\alpha_{5}$ & $\begin{array}{c}-0.459^{* *} \\
(0.207)\end{array}$ & $\begin{array}{c}-1.555^{* *} \\
(0.633)\end{array}$ & $\begin{array}{c}-1.494^{* *} \\
(0.645)\end{array}$ & $\begin{array}{c}-1.371^{*} \\
(0.710)\end{array}$ \\
\hline$\alpha_{-11}$ & $\begin{array}{c}-0.242^{* * *} \\
(0.061)\end{array}$ & $\begin{array}{c}-0.537^{* * *} \\
(0.142)\end{array}$ & $\begin{array}{c}-0.581^{* * *} \\
(0.139)\end{array}$ & $\begin{array}{c}-0.603^{* * *} \\
(0.141)\end{array}$ & $\alpha_{6}$ & $\begin{array}{c}-0.583^{* * *} \\
(0.213)\end{array}$ & $\begin{array}{c}-1.735^{* * *} \\
(0.649)\end{array}$ & $\begin{array}{c}-1.659^{* *} \\
(0.651)\end{array}$ & $\begin{array}{c}-1.533^{* *} \\
(0.711)\end{array}$ \\
\hline$\alpha_{-10}$ & $\begin{array}{c}-0.319^{* * *} \\
(0.069)\end{array}$ & $\begin{array}{c}-0.664^{* * *} \\
(0.158)\end{array}$ & $\begin{array}{c}-0.713^{* * *} \\
(0.155)\end{array}$ & $\begin{array}{c}-0.739^{* * *} \\
(0.158)\end{array}$ & $\alpha_{7}$ & $\begin{array}{c}-0.555^{* *} \\
(0.226)\end{array}$ & $\begin{array}{c}-1.761^{* * *} \\
(0.649)\end{array}$ & $\begin{array}{c}-1.669^{* *} \\
(0.651)\end{array}$ & $\begin{array}{c}-1.539^{* *} \\
(0.717)\end{array}$ \\
\hline$\alpha_{-9}$ & $\begin{array}{c}-0.328^{* * *} \\
(0.078)\end{array}$ & $\begin{array}{c}-0.725^{* * *} \\
(0.173)\end{array}$ & $\begin{array}{c}-0.778^{* * *} \\
(0.169)\end{array}$ & $\begin{array}{c}-0.808^{* * *} \\
(0.172)\end{array}$ & $\alpha_{8}$ & $\begin{array}{r}-0.414^{*} \\
(0.229)\end{array}$ & $\begin{array}{c}-1.677^{* *} \\
(0.652)\end{array}$ & $\begin{array}{c}-1.570^{* *} \\
(0.649)\end{array}$ & $\begin{array}{c}-1.437^{* *} \\
(0.710)\end{array}$ \\
\hline$\alpha_{-8}$ & $\begin{array}{c}-0.468^{* * *} \\
(0.128)\end{array}$ & $\begin{array}{c}-0.840^{* *} \\
(0.335)\end{array}$ & $\begin{array}{c}-0.832^{* *} \\
(0.347)\end{array}$ & $\begin{array}{c}-0.802^{* *} \\
(0.368)\end{array}$ & $\alpha_{9}$ & $\begin{array}{c}-0.540^{* *} \\
(0.239)\end{array}$ & $\begin{array}{c}-1.864^{* * *} \\
(0.665)\end{array}$ & $\begin{array}{c}-1.739^{* * *} \\
(0.660)\end{array}$ & $\begin{array}{c}-1.602^{* *} \\
(0.721)\end{array}$ \\
\hline$\alpha_{-7}$ & $\begin{array}{c}-0.510^{* * *} \\
(0.131)\end{array}$ & $\begin{array}{c}-0.931^{* * *} \\
(0.349)\end{array}$ & $\begin{array}{c}-0.919^{* *} \\
(0.361)\end{array}$ & $\begin{array}{c}-0.890^{* *} \\
(0.383)\end{array}$ & $\alpha_{10}$ & $\begin{array}{c}-0.309 \\
(0.257)\end{array}$ & $\begin{array}{c}-1.004 \\
(0.685)\end{array}$ & $\begin{array}{c}-0.941 \\
(0.747)\end{array}$ & $\begin{array}{c}-0.669 \\
(0.852)\end{array}$ \\
\hline$\alpha-6$ & $\begin{array}{c}-0.544^{* * *} \\
(0.127)\end{array}$ & $\begin{array}{c}-1.017^{* * *} \\
(0.367)\end{array}$ & $\begin{array}{c}-1.003^{* * *} \\
(0.376)\end{array}$ & $\begin{array}{c}-0.974^{* *} \\
(0.399)\end{array}$ & $\alpha_{11}$ & $\begin{array}{c}-0.196 \\
(0.266)\end{array}$ & $\begin{array}{c}-0.920 \\
(0.687)\end{array}$ & $\begin{array}{c}-0.843 \\
(0.750)\end{array}$ & $\begin{array}{c}-0.561 \\
(0.860)\end{array}$ \\
\hline$\alpha_{-5}$ & $\begin{array}{c}-0.544^{* * *} \\
(0.125)\end{array}$ & $\begin{array}{c}-1.066^{* * *} \\
(0.375)\end{array}$ & $\begin{array}{c}-1.046^{* * *} \\
(0.385)\end{array}$ & $\begin{array}{c}-1.018^{* *} \\
(0.407)\end{array}$ & $\alpha_{12}$ & $\begin{array}{c}-0.284 \\
(0.257)\end{array}$ & $\begin{array}{c}-1.032 \\
(0.689)\end{array}$ & $\begin{array}{c}-0.938 \\
(0.740)\end{array}$ & $\begin{array}{c}-0.647 \\
(0.852)\end{array}$ \\
\hline$\alpha_{-4}$ & $\begin{array}{c}-0.327^{* * *} \\
(0.121)\end{array}$ & $\begin{array}{c}-0.898^{* *} \\
(0.382)\end{array}$ & $\begin{array}{c}-0.872^{* *} \\
(0.390)\end{array}$ & $\begin{array}{c}-0.845^{* *} \\
(0.415)\end{array}$ & $\alpha_{13}$ & $\begin{array}{c}-0.427^{*} \\
(0.238)\end{array}$ & $\begin{array}{r}-1.198^{*} \\
(0.672)\end{array}$ & $\begin{array}{c}-1.085 \\
(0.725)\end{array}$ & $\begin{array}{c}-0.785 \\
(0.835)\end{array}$ \\
\hline$\alpha-3$ & $\begin{array}{c}-0.594^{* * *} \\
(0.120)\end{array}$ & $\begin{array}{c}-1.220^{* * *} \\
(0.387)\end{array}$ & $\begin{array}{c}-1.184^{* * *} \\
(0.392)\end{array}$ & $\begin{array}{c}-1.158^{* * *} \\
(0.417)\end{array}$ & $\alpha_{14}$ & $\begin{array}{c}-0.400 \\
(0.251)\end{array}$ & $\begin{array}{r}-1.198^{*} \\
(0.679)\end{array}$ & $\begin{array}{c}-1.066 \\
(0.726)\end{array}$ & $\begin{array}{c}-0.757 \\
(0.840)\end{array}$ \\
\hline$\alpha_{-2}$ & $\begin{array}{c}-0.600^{* * *} \\
(0.116)\end{array}$ & $\begin{array}{c}-1.276^{* * *} \\
(0.388)\end{array}$ & $\begin{array}{c}-1.231^{* * *} \\
(0.390)\end{array}$ & $\begin{array}{c}-1.206^{* * *} \\
(0.415)\end{array}$ & $\alpha_{15}$ & $\begin{array}{r}-0.433^{*} \\
(0.240)\end{array}$ & $\begin{array}{r}-1.255^{*} \\
(0.671)\end{array}$ & $\begin{array}{c}-1.103 \\
(0.707)\end{array}$ & $\begin{array}{c}-0.786 \\
(0.819)\end{array}$ \\
\hline$\alpha_{-1}$ & $\begin{array}{c}-0.463^{* * *} \\
(0.113)\end{array}$ & $\begin{array}{c}-1.195^{* * *} \\
(0.384)\end{array}$ & $\begin{array}{c}-1.139^{* * *} \\
(0.383)\end{array}$ & $\begin{array}{c}-1.116^{* * *} \\
(0.405)\end{array}$ & $\alpha_{16}$ & $\begin{array}{r}-0.486^{*} \\
(0.250)\end{array}$ & $\begin{array}{c}-1.339^{* *} \\
(0.677)\end{array}$ & $\begin{array}{r}-1.168^{*} \\
(0.708)\end{array}$ & $\begin{array}{c}-0.841 \\
(0.818)\end{array}$ \\
\hline$\alpha_{0}$ & $\begin{array}{l}2.992^{* * *} \\
(0.272)\end{array}$ & $\begin{array}{l}2.204^{* * *} \\
(0.506)\end{array}$ & $\begin{array}{l}2.273^{* * *} \\
(0.478)\end{array}$ & $\begin{array}{l}2.294^{* * *} \\
(0.466)\end{array}$ & $\alpha_{17}$ & $\begin{array}{c}-0.601^{* * *} \\
(0.229)\end{array}$ & $\begin{array}{c}-1.484^{* *} \\
(0.728)\end{array}$ & $\begin{array}{r}-1.294^{*} \\
(0.745)\end{array}$ & $\begin{array}{c}-0.958 \\
(0.833)\end{array}$ \\
\hline \multicolumn{6}{|c|}{ Lag cumulative sign-ups } & $\begin{array}{l}0.049^{* * *} \\
(0.014)\end{array}$ & $\begin{array}{l}0.069^{* * *} \\
(0.024)\end{array}$ & $\begin{array}{l}0.067^{* * *} \\
(0.026)\end{array}$ & $\begin{array}{l}0.071^{* * *} \\
(0.026)\end{array}$ \\
\hline \multicolumn{6}{|c|}{$\begin{array}{l}\text { Lag cumulative sign-ups } * \\
\text { within } 45 \text { minutes before threshold dummy }\left(\beta_{1}\right)\end{array}$} & $\begin{array}{c}0.006 \\
(0.006)\end{array}$ & $\begin{array}{c}0.004 \\
(0.007)\end{array}$ & $\begin{array}{c}0.002 \\
(0.007)\end{array}$ & $\begin{array}{c}0.000 \\
(0.008)\end{array}$ \\
\hline \multicolumn{6}{|c|}{ Lag cumulative sign-ups $*$} & -0.004 & -0.007 & -0.008 & -0.011 \\
\hline & $\begin{array}{l}(0.008) \\
-0.008\end{array}$ & $\begin{array}{c}(0.012) \\
-0.018\end{array}$ & $\begin{array}{c}(0.013) \\
-0.018\end{array}$ & $\begin{array}{l}(0.014) \\
-0.023\end{array}$ \\
\hline \multicolumn{6}{|c|}{ from 45 minutes to 90 minutes after threshold dummy $\left(\beta_{3}\right)$} & $(0.010)$ & $(0.014)$ & $(0.016)$ & $(0.017)$ \\
\hline \multicolumn{6}{|c|}{ Time-of-the-day fixed effects } & Yes & Yes & Yes & Yes \\
\hline \multicolumn{6}{|c|}{ Deal fixed effects } & Yes & Yes & Yes & Yes \\
\hline \multicolumn{6}{|c|}{ Number of observations } & 147,112 & 142,904 & 142,904 & 142,904 \\
\hline \multicolumn{6}{|c|}{ Number of deals } & 4,208 & 4,208 & 4,208 & 4,208 \\
\hline \multicolumn{6}{|c|}{ Adjusted R-squared } & 0.389 & & & \\
\hline
\end{tabular}

Note: Dependent variable is the number of new sign-ups per 5-min time interval. Standard errors are clustered by deal and reported in parentheses. ${ }^{* * *} p<0.01,{ }^{* *} p<0.05,{ }^{*} p<0.1$.

Table 7 shows the regression results of our extended model. The result from the GLS estimator is presented as a benchmark. We show the results from the GMM estimator using two, three and four lags of GMM instrumental variables. Specifically, GMM instruments include the lagged cumulative number of sign-ups, and the lagged interaction terms between the 45-minute time dummies and the cumulative number of sign-ups. In theory, we can use all valid lagged regressors, 
i.e., those with lags of two and more. However, the number of instruments would be quadratic in the time dimension of the panel, and the GMM estimator may perform poorly with a large number of instruments (Roodman 2009). Too many instruments may overfit endogenous variables, bias coefficient estimates, and thus the results from the finite sample may be far from the asymptotic ideal. In our analysis, we apply the GMM estimator using two, three and four lags of instrumental variables. As shown in columns 2, 3 and 4 in Table 7, the results are robust with respect to the number of lags used.

Figure 2 Estimated Sign-Up Pattern during the One-and-a-half-hour Time Window before and after the Threshold was Reached.

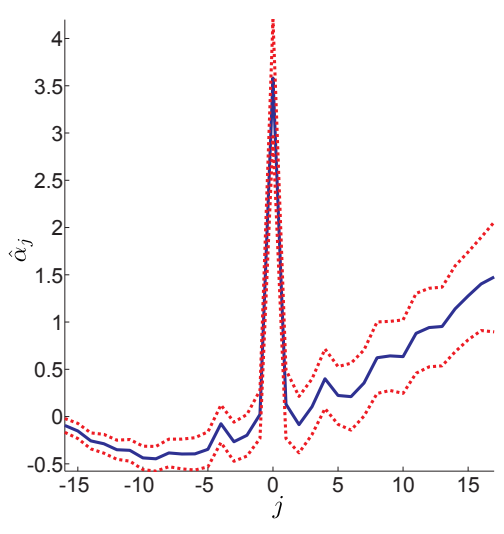

(a) The base model

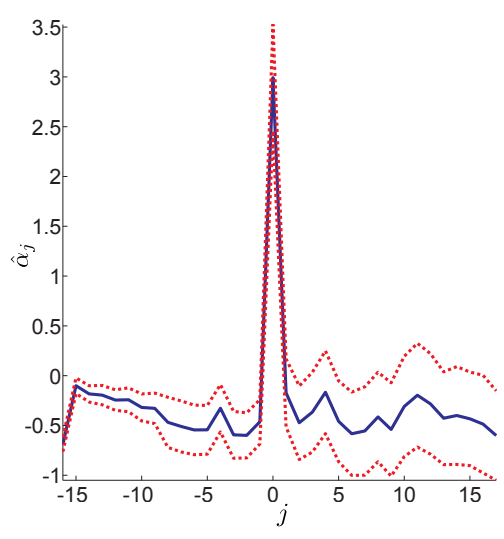

(b) The extended model (GLS)

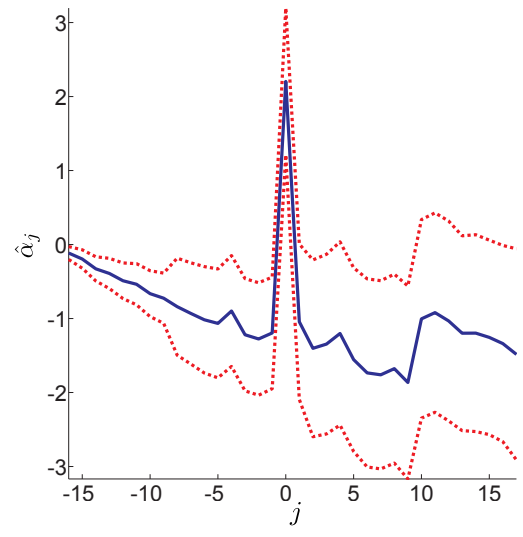

(c) The extended model (GMM)

Note. The solid lines in figures (a), (b) and (c) denote the estimated coefficients of time dummies, i.e., $\hat{\alpha}_{j}, j=$ $-16, \ldots, 17$, from the base model, the extended model using GLS estimator and the extended model using GMM estimator with 2 lags, respectively. The dotted lines are $95 \%$ confidence intervals.

The estimated coefficients of time dummies, i.e., $\hat{\alpha}_{j}, j=-16, \ldots, 17$, using the GLS estimator and GMM estimator (with 2 lags) are plotted in Figure 2(b) and Figure 2(c), respectively. After controlling for the lagged cumulative number of sign-ups, the surge in the number of sign-ups during the interval when the threshold was reached still remains. We further verify this finding by conducting Wald tests on the differences between the estimated coefficients of the time dummy when the threshold was reached, and other time dummies within the half-an-hour time window either before or after the threshold was reached. As shown in the first part of Table 8, the differences between the coefficients are all statistically significant. To facilitate the comparison of 
Table $8 \quad$ Statisical Tests using Estimates in Table 7.

\begin{tabular}{|c|c|c|c|c|c|c|c|c|c|}
\hline & GLS G & GMM(2 lags) & GMM(3 lags) & GMM(4 lags) & & GLS C & GMM(2 lags) & $\operatorname{GMM}(3$ lags $)$ & GMM(4 lags) \\
\hline \multirow[t]{2}{*}{$\alpha_{0}-\alpha_{-5}$} & $3.535^{* * *}$ & $3.270^{* * *}$ & $3.319^{* * *}$ & $3.312^{* * *}$ & $\alpha_{0}-\alpha_{1}$ & $3.164^{* * *}$ & $3.248^{* * *}$ & $3.302^{* * *}$ & $3.215^{* * *}$ \\
\hline & $(0.330)$ & $(0.335)$ & $(0.335)$ & $(0.327)$ & & $(0.303)$ & $(0.348)$ & $(0.369)$ & $(0.388)$ \\
\hline \multirow[t]{2}{*}{$\alpha_{0}-\alpha_{-4}$} & $3.319^{* * *}$ & $3.102^{* * *}$ & $3.145^{* * *}$ & $3.139^{* * *}$ & $\alpha_{0}-\alpha_{2}$ & $3.465^{* * *}$ & $3.607^{* * *}$ & $3.651^{* * *}$ & $3.559^{* * *}$ \\
\hline & $(0.323)$ & $(0.325)$ & $(0.326)$ & $(0.320)$ & & $(0.330)$ & $(0.392)$ & $(0.417)$ & $(0.444)$ \\
\hline \multirow[t]{2}{*}{$\alpha_{0}-\alpha_{-3}$} & $3.586^{* * *}$ & $3.423^{* * *}$ & $3.457^{* * *}$ & $3.452^{* * *}$ & $\alpha_{0}-\alpha_{3}$ & $3.358^{* * *}$ & $3.550^{* * *}$ & $3.582^{* * *}$ & $3.487^{* * *}$ \\
\hline & $(0.312)$ & $(0.312)$ & $(0.314)$ & $(0.309)$ & & $(0.348)$ & $(0.418)$ & $(0.437)$ & $(0.466)$ \\
\hline \multirow[t]{2}{*}{$\alpha_{0}-\alpha_{-2}$} & $3.591^{* * *}$ & $3.480^{* * *}$ & $3.504^{* * *}$ & $3.500^{* * *}$ & $\alpha_{0}-\alpha_{4}$ & $3.158^{* * *}$ & $3.406^{* * *}$ & $3.427^{* * *}$ & $3.328^{* * *}$ \\
\hline & $(0.304)$ & $(0.303)$ & $(0.305)$ & $(0.301)$ & & $(0.337)$ & $(0.416)$ & $(0.437)$ & $(0.463)$ \\
\hline \multirow[t]{2}{*}{$\alpha_{0}-\alpha_{-1}$} & $3.455^{* * *}$ & $3.399^{* * *}$ & $3.412^{* * *}$ & $3.410^{* * *}$ & $\alpha_{0}-\alpha_{5}$ & $3.451^{* * *}$ & $3.759^{* * *}$ & $3.767^{* * *}$ & $3.665^{* * *}$ \\
\hline & $(0.296)$ & $(0.295)$ & $(0.296)$ & $(0.295)$ & & $(0.328)$ & $(0.412)$ & $(0.431)$ & $(0.461)$ \\
\hline \multirow[t]{2}{*}{$\beta_{1}-\beta_{2}$} & $0.010^{* * *}$ & $0.011^{*}$ & 0.009 & $0.010^{*}$ & $\beta_{2}-\beta_{3}$ & 0.004 & $0.011^{* * *}$ & $0.010^{* * *}$ & $0.011^{* * *}$ \\
\hline & $(0.003)$ & $(0.006)$ & $(0.006)$ & $(0.007)$ & & $(0.003)$ & $(0.003)$ & $(0.003)$ & $(0.003)$ \\
\hline
\end{tabular}

Note: Standard errors are clustered by deal and reported in parentheses. Significance levels are related to the null hypothesis $H_{0}$ : combination of coefficients $=0 .{ }^{* *} p<0.01,{ }^{* *} p<0.05,{ }^{*} p<0.1$.

this effect across different cities and product categories, we define a spike index as the measure for the additional number of sign-ups due to the thresholds. Specifically, the spike index is equal to $\sum_{j=-5}^{5}\left(\hat{\alpha}_{0}-\hat{\alpha}_{j}\right) / 10$. Using the results from the GMM estimator with 2 lags, the spike index across all deals is 3.424. That is, on average, around 3.424 more consumers would sign up to the deal during the 5-minute time interval when the threshold was reached (statistically significant, $p<0.01)$. To assess the magnitude of this effect, note that during the half-an-hour time window before and after the threshold was reached, on average there were approximately 3.6 consumers signing up ever 5 minutes. Thus, the existence of thresholds produces a substantial boost in sales.

The level shift in the ratio between the new sign-ups and the cumulative number of sign-ups as suggested in Figure 1(b) also remains after we control for time-of-the-day effects and deal fixed effects. Specifically, our test results show that the ratio in the 45-minute time window before the thresholds is higher than that in the 45-minute time window after the thresholds by around 0.01 , which is consistent among the results from GLS estimator and GMM estimator with various lags (see test results of $\beta_{1}-\beta_{2}$ in Table 8 ). The difference in the ratio before and after the thresholds is significant from the GLS estimator and GMM estimator using either 2 lags or 4 lags. However, the difference is insignificant from the GMM estimator using 3 lags. The underlying reason might 
be the weak instruments for 3 and 4 lags to be discussed below. The estimated coefficients from the GMM estimator also indicate that the ratio between new sign-ups and the cumulative number of sign-ups continues decreasing after reaching the thresholds (see test results on $\beta_{2}-\beta_{3}$ in Table 8). After the thresholds, the ratio in the second 45-minute time period is significantly lower than that in the first 45-minute time window.

It is worth noting that the validity of the GMM estimator will be violated if the error component $\epsilon_{i, t}$ is serially correlated over time. To address this concern, we apply post-estimation tools of the GMM estimator and examine the serial correlation structure of the new error component $\epsilon_{i, t}-\epsilon_{i, t-1}$. The second-order serial correlation is $-0.662(p=0.508)$, suggesting that the error components in Equation (2), i.e., $\epsilon_{i, t}$, are indeed uncorrelated over time.

Table 9 F-statistics for the Instrumental Variable Regressions.

\begin{tabular}{lrrr}
\hline & 2 lags & 3 lags & 4 lags \\
\cline { 2 - 4 } F-statistic of $Y_{i, t-1}$ & 18.03 & 16.32 & 12.56 \\
F-statistic of $Y_{i, t-2}$ & 11.37 & 0.40 & 0.36 \\
F-statistic of $Y_{i, t-3}$ & & 13.21 & 0.24 \\
F-statistic of $Y_{i, t-4}$ & & & 7.23 \\
\hline
\end{tabular}

Another potential concern with the GMM estimator is weak instruments. When the correlation between instrumental variables and the endogenous variable is low, the asymptotic distribution of the coefficients breaks down, and GMM estimates may not be consistent (Bound et al. 1995). In this case, the standard errors on GMM estimates are likely to be larger than those on GLS estimates. For our model, the concern of weak instruments may become important if the lagged cumulative number of sign-ups is not informative in predicting the new sign-ups. To test the existence of weak instruments, we regress the endogenous variable after the first-difference transformation, i.e., $y_{i, t}$, on various lags of cumulative number of sign-ups. The regression analysis is conducted using 2 lags to 4 lags, and the F-statistics are summarized in Table 9. We refer to the rule of thumb suggested by Staiger and Stock (1997) that the finite-sample bias of instrumental variables would not be a serious problem when the F-statistic is greater than 10. When we use only two lags, the F-statistics 
on both lags are greater than the cut-off value of 10 . However, the results with more than 2 lags show that the correlation between the number of new sign-ups and some lagged cumulative number of sign-ups is low. Since the incremental number of sign-ups within a short period of time is likely to be highly correlated, utilizing more lagged cumulative number of sign-ups may not increase the power in predicting the number of new sign-ups, rendering some lagged variables as weak instruments. Based on the above test results, in the subsequent analysis we will report only the results from GMM estimator with two lags. We will continue reporting results from GLS estimator as the benchmark.

Table 10 Statistical Tests using Category Level Regression Results.

\begin{tabular}{|c|c|c|c|c|c|c|}
\hline & \multicolumn{2}{|c|}{ Spike Index } & \multicolumn{2}{|c|}{$\beta_{1}-\beta_{2}$} & \multicolumn{2}{|c|}{$\beta_{2}-\beta_{3}$} \\
\hline & GLS & $\operatorname{GMM}(2$ lags $)$ & GLS & GMM(2 lags) & GLS & $\operatorname{GMM}(2$ lags $)$ \\
\hline \multirow[t]{2}{*}{ Arts } & $5.110^{* * *}$ & $5.002^{* * *}$ & -0.002 & 0.003 & -0.007 & -0.006 \\
\hline & $(1.356)$ & $(1.254)$ & $(0.007)$ & $(0.007)$ & $(0.005)$ & $(0.005)$ \\
\hline \multirow[t]{2}{*}{ Sports } & $3.499^{* * *}$ & $3.833^{* * *}$ & $0.018^{* * *}$ & 0.006 & $0.006^{* * *}$ & $0.007^{*}$ \\
\hline & $(0.302)$ & $(0.337)$ & $(0.006)$ & $(0.008)$ & $(0.002)$ & $(0.004)$ \\
\hline \multirow[t]{2}{*}{ Beauty } & $4.072^{* * *}$ & $4.361^{* * *}$ & 0.001 & -0.013 & $0.005^{* *}$ & -0.000 \\
\hline & $(1.002)$ & $(1.202)$ & $(0.011)$ & $(0.024)$ & $(0.002)$ & $(0.011)$ \\
\hline \multirow[t]{2}{*}{ Fast Food } & $6.207^{* * *}$ & $6.955^{* * *}$ & 0.007 & -0.017 & -0.002 & -0.004 \\
\hline & $(2.296)$ & $(2.553)$ & $(0.009)$ & $(0.024)$ & $(0.012)$ & $(0.011)$ \\
\hline \multirow[t]{2}{*}{ American Food } & $2.900^{* * *}$ & $3.069^{* * *}$ & $0.007^{*}$ & 0.004 & $0.011^{* * *}$ & $0.011^{* * *}$ \\
\hline & $(0.318)$ & $(0.409)$ & $(0.004)$ & $(0.006)$ & $(0.003)$ & $(0.004)$ \\
\hline \multirow[t]{2}{*}{ Other Food } & $1.971^{* * *}$ & $2.165^{* * *}$ & $0.021^{* * *}$ & $0.016^{* * *}$ & $0.009^{* * *}$ & 0.005 \\
\hline & $(0.247)$ & $(0.253)$ & $(0.002)$ & $(0.004)$ & $(0.002)$ & $(0.004)$ \\
\hline \multirow[t]{2}{*}{ Other Products } & $2.331^{* * *}$ & $2.433^{* * *}$ & $0.009^{* *}$ & 0.002 & $0.012^{* * *}$ & 0.000 \\
\hline & $(0.208)$ & $(0.242)$ & $(0.004)$ & $(0.008)$ & $(0.004)$ & $(0.008)$ \\
\hline
\end{tabular}

Note: Standard errors are clustered by deal and reported in parentheses. Significance levels are related to the null hypothesis $H_{0}$ : combination of coefficients $=0 .{ }^{* * *} p<0.01,{ }^{* *} p<0.05,{ }^{*} p<0.1$.

\subsection{Heterogeneous Threshold Effects across Categories and Cities}

3.4.1. Category Level Regression Results. To further understand threshold effects, we investigate how such effects may vary across product categories. We select seven categories with the largest number of observations, and estimate the extended model using GMM estimator for each of these seven product categories. The estimates and related test results are listed in Table 
A1 and Table 10, respectively. The test results show that the spike index is statistically significant in all categories. The values of the index range from 2.165 to 6.955 , which suggests a significant increase in the number of sign-ups around the time the threshold was reached.

The test results on the relationship between the number of new sign-ups and the cumulative number of sign-ups show significant variations across product categories. Specifically, results from the GLS estimator show that the ratio during the 45-minute time period is significantly higher before reaching the thresholds than afterwards in four categories, namely, Sports 8 Recreation, American Food, Other Food and Other Physical Products. The differences are only significant in Other Food from the GMM estimator. Moreover, under both estimators, two of the seven selected categories show a clear downward trend after the thresholds were reached.

3.4.2. City Level Regression Results. Next we examine whether the threshold effects vary across different cities. To explore this issue, we divide the deals into four groups according to the population of the city where deals were offered, and estimate the extended model for each subsample separately. The estimates for each category of city populations are summarized in Table A2, and the relevant statistical test results are listed in Table 11.

Table 11 Statisitcal Tests using Population-categorized Regression Results.

\begin{tabular}{|c|c|c|c|c|c|c|}
\hline & \multicolumn{2}{|c|}{ Spike Index } & \multicolumn{2}{|c|}{$\beta_{1}-\beta_{2}$} & \multicolumn{2}{|c|}{$\beta_{2}-\beta_{3}$} \\
\hline & GLS & GMM(2 lags) & GLS & $\operatorname{GMM}(2$ lags $)$ & GLS & $\operatorname{GMM}(2$ lags $)$ \\
\hline \multirow[t]{2}{*}{$<0.25 \mathrm{mil}$} & $3.375^{* * *}$ & $3.209^{* * *}$ & 0.001 & 0.019 & -0.002 & $0.012^{* * *}$ \\
\hline & $(0.566)$ & $(0.539)$ & $(0.009)$ & $(0.014)$ & $(0.006)$ & $(0.003)$ \\
\hline \multirow[t]{2}{*}{$0.25-0.5 \mathrm{mil}$} & $3.054^{* * *}$ & $3.169^{* * *}$ & $0.014^{* *}$ & $0.007^{* *}$ & $0.010^{* * *}$ & 0.007 \\
\hline & $(0.221)$ & $(0.208)$ & $(0.005)$ & $(0.004)$ & $(0.003)$ & $(0.006)$ \\
\hline \multirow[t]{2}{*}{$0.5-1 \mathrm{mil}$} & $3.458^{* * *}$ & $3.846^{* * *}$ & 0.001 & -0.013 & $0.007^{*}$ & 0.006 \\
\hline & $(0.505)$ & $(0.705)$ & $(0.007)$ & $(0.017)$ & $(0.004)$ & $(0.009)$ \\
\hline \multirow[t]{2}{*}{$>1 \mathrm{mil}$} & $4.498^{* * *}$ & $4.569^{* * *}$ & $0.013^{* * *}$ & $0.012^{* * *}$ & 0.001 & $0.006^{* *}$ \\
\hline & $(1.387)$ & $(1.254)$ & $(0.004)$ & $(0.003)$ & $(0.006)$ & $(0.003)$ \\
\hline
\end{tabular}

Note: Standard errors are clustered by deal and reported in parentheses. Significance levels are related to the null hypothesis $H_{0}$ : combination of coefficients $=0 .{ }^{* * *} p<0.01,{ }^{* *} p<0.05,{ }^{*} p<0.1$.

Similar to our category level analysis, the spike indexes are statistically significant across all population categories. More interestingly, the test results on the ratio before and after the thresholds show stark contrast among cities of different sizes. Our result suggests that the differences 
in the ratio before and after the thresholds exhibit a $U$-shape relationship with the size of cities: the differences are significant in the largest cities with over 1 million populations, as well as the relatively small cities with less than 500,000 but over 250,000 populations; however, there is no evidence of significant differences in the mid-size cities. No single type of cities shows consistent downward trend after the thresholds from both estimators.

Table 12 Statisitcal Tests using Regional Level Regression Results.

\begin{tabular}{|c|c|c|c|c|c|c|}
\hline & \multicolumn{2}{|c|}{ Spike Index } & \multicolumn{2}{|c|}{$\beta_{1}-\beta_{2}$} & \multicolumn{2}{|c|}{$\beta_{2}-\beta_{3}$} \\
\hline & GLS & $\operatorname{GMM}(2$ lags $)$ & GLS & $\operatorname{GMM}(2$ lags $)$ & GLS & $\operatorname{GMM}(2$ lags $)$ \\
\hline \multirow[t]{2}{*}{ West } & $2.829^{* * *}$ & $2.983^{* * *}$ & 0.006 & 0.002 & 0.002 & $0.008^{* * *}$ \\
\hline & $(0.234)$ & $(0.222)$ & $(0.005)$ & $(0.005)$ & $(0.003)$ & $(0.003)$ \\
\hline \multirow[t]{2}{*}{ Midwest } & $3.892^{* * *}$ & $3.929^{* * *}$ & 0.011 & 0.007 & $0.008^{* * *}$ & 0.007 \\
\hline & $(0.705)$ & $(0.680)$ & $(0.007)$ & $(0.010)$ & $(0.002)$ & $(0.006)$ \\
\hline \multirow[t]{2}{*}{ South } & $4.020^{* * *}$ & $4.096^{* * *}$ & 0.007 & 0.007 & -0.001 & 0.009 \\
\hline & $(0.740)$ & $(0.743)$ & $(0.005)$ & $(0.016)$ & $(0.007)$ & $(0.005)$ \\
\hline \multirow[t]{2}{*}{ Northeast } & $2.672^{* * *}$ & $2.736^{* * *}$ & $0.015^{* * *}$ & $0.013^{* * *}$ & $0.009^{* * *}$ & $0.008^{* *}$ \\
\hline & $(0.251)$ & $(0.247)$ & $(0.003)$ & $(0.003)$ & $(0.003)$ & $(0.003)$ \\
\hline \multirow[t]{2}{*}{ Canada } & $2.924^{* * *}$ & $3.405^{* * *}$ & -0.001 & $-0.027^{*}$ & 0.004 & -0.010 \\
\hline & $(0.412)$ & $(0.440)$ & $(0.007)$ & $(0.014)$ & $(0.005)$ & $(0.006)$ \\
\hline
\end{tabular}

Note: Standard errors are clustered by deal and reported in parentheses. Significance levels are related to the null hypothesis $H_{0}$ : combination of coefficients $=0 .{ }^{* * *} p<0.01,{ }^{* *} p<0.05,{ }^{*} p<0.1$.

We also analyze the data by categorizing the deals by geographic region. The result, as shown in Table A3 and Table 12, is similar to our results categorized according to city population. The spike indexes are statistically significant across all regions. The difference in the ratio before and after the thresholds were reached is shown to be the most significant in markets within the Northeast region, while the differences are marginally significant or insignificant in the other four regions. Finally, the ratio shows a consistent downward trend after the thresholds were reached in the Northeast region, as well.

\section{Potential Mechanisms behind Threshold Effects}

Our analysis in previous sections has documented and substantiated two types of threshold effects in online group buying. However, the aggregate nature of the data prevents us from identifying the 
exact mechanisms contributing to these effects. In this section, we discuss several mechanisms that are compatible with the findings and thus can serve as potential hypotheses for future research. ${ }^{1}$

For the first type of threshold effects, i.e., the sudden surge of sign-ups around the time when thresholds were reached, we consider three possible mechanisms: value enhancement, postponed decision making and correlated consumer awareness of deals. First, a consumer may derive positive psychological value from beating a target. When the cumulative number of sign-ups approaches the threshold, the urge to beat a target becomes salient to consumers. Consequently, these consumers may behave in a "frenzy" fashion due to their eagerness to beat the threshold, leading to a substantial increase in the number of sign-ups around the time when the threshold was reached. This phenomenon is similar to "bidding frenzy" widely reported in the auction literature to explain the irrational bidding behavior towards the end of the auction period (see, e.g., Ku et al. 2005, Heyman et al. 2004). The "frenzy" was described as a mental state "characterized by a high level of excitement, a strong sense of competition, and an intense desire to win" (Häubl and Popkowski Leszczyc 2004). Bidding frenzy leads to a considerable share of bids being submitted around the closing time of auctions (Roth and Ockenfels 2002, Ockenfels et al. 2006).

Second, the temporal surge in the number of sign-ups may arise from some consumers' decisions to postpone their actions till the deals are on or about to be on. Before the threshold is reached, a consumer faces uncertainty on deal success and the risk that at the end, they will not receive the discounted product or service. The consumer may then consider postponing the sign-up decision if it is not too costly to constantly track the cumulative sign-up numbers. Such postponement of action could also lead to a surge in the number of sign-ups around the time when the threshold was reached.

Third, the number of sign-ups may surge around the thresholds because consumer awareness to the deal increased at the same time. Such an increase in consumer awareness can be driven by firm's communication strategy. For example, when a deal comes close to its threshold, a groupbuying firm like Groupon may feature the deal on its front page or highlight the deal in its email

\footnotetext{
${ }^{1}$ We thank the AE and anonymous reviewers for suggesting many alternative mechanisms.
} 
to the subscribers. The firm may also coordinate with third-party deal aggregators to enhance the placement of those deals on the third-party websites.

For the second type of threshold effects, i.e., the level shift of the ratio between the number of new sign-ups and the cumulative number of sign-ups before and after the thresholds were reached, we discuss four alternative mechanisms: word-of-mouth referral, observational learning, consumer heterogeneity, and demand satiation. First, it is commonly known that people who have already signed up to deals play an active role in disseminating deal information. In our model, the positive relation between the number of new sign-ups and the cumulative number of sign-ups could be used to capture the intensity of referrals (e.g., Bass et al. 1994). Following this logic, our regression results would suggest that the intensity of referrals is stronger before the thresholds are reached. This result is consistent with the view of group buying business as a marketing tool to exploit social interactions between consumers. For instance, Jing and Xie (2011) suggest that consumers are heterogeneous in their awareness and knowledge of the deals, leading to differences in deal valuations. Those consumers with high valuations are more likely to sign up for the deal, but they face the possibility of deal failure if there is an insufficient number of people signing up for the deal. Group buying deals may motivate the informed consumers to spread the deal information to their social contacts and use their social relationship to persuade them to join the deal. Jing and Xie (2011) extract many quotes from online communications to demonstrate that group buying could turn informed consumers into sales agents to convert the uninformed consumers.

Second, herding behavior or observational learning may explain the positive relation between the number of new sign-ups and the cumulative number of sign-ups, as demonstrated in Zhang and Liu (2012). In the context of group buying, some consumers can be uncertain about the true quality of the suppliers and hence the value of the deals. These consumers may infer the quality of merchants by the number of consumers who have already signed up to the deal. Following this rationale, the level shift of $\beta_{j}$ can be interpreted as a greater impact of learning before the thresholds were reached. When a deal is off, those who have already signed up will typically receive a full refund. Nevertheless, these consumers would incur psychological loss and opportunity costs of time and 
money. Our result suggests that under the riskier environment, i.e., before the thresholds were reached, individual consumers are more likely to resort to the decisions of others in making their own purchase decisions.

Third, the second type of threshold effects could be explained by the heterogeneity between consumer populations arriving at the deal site at different time periods. Consumers may have different levels of knowledge and skills in working with Internet and online social media. Those techsavvy users may find it easy to keep track of the Groupon website. As a result, these consumers may learn about the deals and sign up earlier than others. Meantime, this same cohort of consumers are more capable of engaging in referrals through online social networks, leading to a stronger positive relation between the new sign-ups and the cumulative number of sign-ups before the thresholds were reached. Consumers could also be heterogeneous in their perception of others' awareness of daily deals before and after the thresholds. Those who arrive earlier (before the thresholds) might infer that others may not have heard about the deal, and thus are more likely to share it with others. On the other hand, consumers who come across the deal in later periods (especially after the thresholds) might think that others must have heard about the deal, and choose not to share it.

Finally, the second type of threshold effects could be due to the satiation in both the market demand and the reach of word-of-mouth referrals. If the satiation levels happen to be reached around the same time when threshold was reached, then we would observe, on average, more sign-ups per 5-minute interval before the thresholds than afterwards.

The mechanisms discussed above have different implications on the economic impact of threshold effects. Based on the GMM estimator with 2 lags, on average there were 3.4 additional sign-ups during the periods when thresholds were reached. Moreover, the relation between the new sign-ups and the cumulative number of sign-ups experienced a drop right after reaching the thresholds and continued the decreasing trend afterwards. To accurately quantify the economic implications of threshold effects, it is necessary to account for specific underlying mechanisms. For example, for the first-type of threshold effects, one needs to know the extent of inter-temporal substitutions, 
i.e., whether some consumers might sign up sooner or later if thresholds did not exist. Similarly, for the second-type of threshold effects, one needs to confirm if word-of-mouth referral was the driving force. As data limitation prevents us from identifying such specific mechanisms, we leave to future research to investigate the economic implications of threshold effects.

\section{Conclusion}

Our paper empirically studies two types of threshold-induced effects on sign-up behavior in online group buying. The first type of threshold effects refers to a substantial increase in the number of sign-ups around the time when the threshold was reached, and the second type of threshold effects refers to a stronger positive relation between the number of new sign-ups and the cumulative number of sign-ups before reaching the thresholds than afterwards. Using the GMM estimator, we find that the first type of threshold effects exists consistently across all product categories and in all geographic locations. The second type of threshold effects, while being significant overall, is strong in the category of Other Food but weak in other categories. The second type of threshold effects is most significant in the markets of the Northeast region of U.S. These results imply that threshold effects could vary significantly across products and markets. Thus, managers may need to consider the product and local market characteristics when making decisions on the use of thresholds for group-buying deals.

While our research offers useful insights about the threshold-induced behavior in the online group buying context, future research is required to enrich our understanding of the issue. First, although our research shows evidence for the threshold-induced effects, we do not directly observe individual level behavior. While we propose several potential mechanisms that are compatible to our empirical findings, further research is needed to identify the specific driving forces behind these effects. Second, the group-buying deals offered by Groupon had a single threshold for each deal. A more general group-buying mechanism could have multiple thresholds. For example, fundraising site Kickstarter.com and many early group-buying sites like Mercata have used multiple levels of thresholds. Typically, a greater reward is offered for achieving a higher threshold. Future research can investigate if the threshold effects may diminish or enhance when higher thresholds come close. 


\section{Acknowledgement}

The authors thank the department editor, the associate editor, and three anonymous reviewers for their guidance and constructive comments.

\section{References}

Anand, K. S., R. Aron. 2003. Group Buying on the Web: A Comparison Mechanism of Price-Discovery. Management Sci. 49(11) 1546-1562.

Arellano, M., S. Bond. 1991. Some Tests of Specification for Panel Data: Monte Carlo Evidence and an Application to Employment Equations. Rev. of Econom. Stud. 58(2) 277-297.

Bass, F. M., T. V. Krishnan, D. C. Jain. 1994. Why the Bass Model Fits without Decision Variables. Marketing Sci. 13(3) 203-223.

Bound, J., D. A. Jaeger, R. M. Baker. 1995. Problems with Instrumental Variables Estimation When the Correlation Between the Instruments and the Endogeneous Explanatory Variable is Weak. J. of the Amer. Statistical Association 90(430) 443-450.

Byers, J. W., M. Mitzenmacher, Zervas G. 2012. Daily Deals: Prediction, Social Diffusion, and Reputational Ramifications. Proceedings of the Fifth ACM Int'l Conference on Web Search and Data Mining. Seattle, WA.

Chen, J., X. Chen, X. Song. 2007. Comparison of the Group-Buying Auction and the Fixed Pricing Mechanism. Decision Support Systems 43(2) 445-459.

Dholakia, U. M. 2010. How Effective are Groupon Promotions for Businesses? Working Paper, Rice University, TX.

Edelman, B., S. Jaffe, S. D. Kominers. 2010. To Groupon or Not to Groupon: The Profitability of Deep Discounts. Working Paper, Harvard University, MA.

Fowler, G. A. 2010. Groupon Grows beyond One Deal per Day. The Wall Street Journal Blogs.

Häubl, G., P. T. L. Popkowski Leszczyc. 2004. Bidding Frenzy: Intensity of Competitive Interaction among Bidders and Product Valuation in Auctions. Advances in Consumer Res. 31 90-93.

Heyman, J. E., Y. Orhun, D. Ariely. 2004. Auction Fever: The Effect of Opponents and Quasi-Endowment on Product Valuations. J. of Interactive Marketing 18(4) 7-21. 
Hu, M., M. Shi, J. Wu. 2013. Simultaneous vs. Sequential Group-Buying Mechanisms. Management Sci. forthcoming.

Jing, X., J. Xie. 2011. Group Buying: A New Mechanism for Selling through Social Interactions. Management Sci. 57(8) 1354-1372.

Kauffman, R. J., B. Wang. 2002. Bid Together, Buy Together: On the Efficacy of Group-Buying Business Models in Internet-Based Selling. The E-Business Handbook. CRC Press, Boca Ration, FL.

Ku, G., D. Malhotra, J. K. Murnighan. 2005. Towards a Competitive Arousal Model of Decision-Making: A Study of Auction Fever in Live and Internet Auctions. Organizational Behavior and Human Decision Processes 96(2) 89-103.

Li, X., L. Wu. 2012. Measuring Effects of Observational Learning and Social-Network Word-of-Mouth on the Sales of Daily-Deal Vouchers. Workshop on Information Systems and Economics. Orlando, FL.

Nickell, S. 1981. Biases in Dynamic Models with Fixed Effects. Econometrica 49(6) 1417-1426.

Ockenfels, A., D. Reiley, A. Sadrieh. 2006. Online Auctions. NBER Working Papers 12785.

Pepitone, J. 2011. Groupon Anxiety: The Online-Coupon Firm Will Have to Move Fast to Retain its Impressive Lead. Economist.

Roodman, D. 2009. A Note on the Theme of Too Many Instruments. Oxford Bulletin of Economics and Statistics 71(1) 135-158.

Roth, A. E., A. Ockenfels. 2002. Last-Minute Bidding and the Rules for Ending Second-Price Auctions: Evidence from eBay and Amazon Auctions on the Internet. Amer. Econom. Rev. 92(4) 1093-1103.

Staiger, D., J. H. Stock. 1997. Instrumental Variables Regressions with Weak Instruments. Econometrica $\mathbf{6 5}(3) 557-586$.

Villas-Boas, J. M., R. S. Winer. 1999. Endogeneity in Brand Choice Models. Management Sci. 45(10) $1324-1338$.

Zhang, J., P. Liu. 2012. Rational Herding in Microloan Markets. Management Sci. 58(5) 892-912. 


\section{Appendix: Tables.}

Table A1 Category Level Regression Results from Three-hour Data using GMM Estimator with 2 Lags.

\begin{tabular}{|c|c|c|c|c|c|c|c|c|c|c|c|c|c|c|c|}
\hline & irts & ports & eauty & $\begin{array}{l}\text { Fast } \\
\text { Food }\end{array}$ & $\begin{array}{l}\text { American } \\
\text { Food }\end{array}$ & $\begin{array}{l}\text { Other } \\
\text { Food }\end{array}$ & $\begin{array}{c}\text { Other } \\
\text { Products }\end{array}$ & & rits & ports & eauty & $\begin{array}{l}\text { Fast } \\
\text { Food }\end{array}$ & $\begin{array}{l}\text { merican } \\
\text { Food }\end{array}$ & $\begin{array}{l}\text { Other } \\
\text { Food }\end{array}$ & $\begin{array}{c}\text { Other } \\
\text { Products }\end{array}$ \\
\hline-16 & $\begin{array}{c}-0.177 \\
(0.148)\end{array}$ & $\begin{array}{c}-0.021 \\
(0.136)\end{array}$ & $\begin{array}{c}-0.223 \\
(0.147)\end{array}$ & $\begin{array}{c}-0.103 \\
(0.161)\end{array}$ & $\begin{array}{c}-0.421^{* * *} \\
(0.158)\end{array}$ & $\begin{array}{c}* 0.065 \\
(0.167)\end{array}$ & $\begin{array}{c}0.009 \\
(0.083)\end{array}$ & $\alpha_{1}$ & $\begin{array}{l}-1.617^{* * *} \\
(0.607)\end{array}$ & $\begin{array}{c}* * 0.907^{* *} \\
(0.451)\end{array}$ & $\begin{array}{c}{ }^{*}-3.236^{*} \\
(1.914)\end{array}$ & $\begin{array}{c}-0.345 \\
(1.582)\end{array}$ & $\begin{array}{c}-1.554^{* * *} \\
(0.508)\end{array}$ & $\begin{array}{r}* 0.259 \\
(0.391)\end{array}$ & $\begin{array}{c}-0.693^{* *} \\
(0.333)\end{array}$ \\
\hline-15 & $\begin{array}{c}-0.119 \\
(0.158)\end{array}$ & $\begin{array}{c}-0.210 \\
(0.135)\end{array}$ & $\begin{array}{c}-0.464^{*} \\
(0.252)\end{array}$ & $\begin{array}{r}-0.277 \\
(0.182)\end{array}$ & $\begin{array}{c}0.077 \\
(0.192)\end{array}$ & $\begin{array}{c}-0.157 \\
(0.138)\end{array}$ & $\begin{array}{c}-0.084 \\
(0.075)\end{array}$ & $\alpha_{2}$ & $\begin{array}{l}-2.099^{* *}= \\
(0.745)\end{array}$ & $\begin{array}{c}*{ }^{*} 1.048^{* *} \\
(0.470)\end{array}$ & $\begin{array}{r}-4.471^{*} \\
(2.555)\end{array}$ & $\begin{array}{l}0.074 \\
(1.682)\end{array}$ & $\begin{array}{l}-1.958^{* * *} \\
(0.622)\end{array}$ & * $\begin{array}{c}0.090 \\
(0.404)\end{array}$ & $\begin{array}{c}-0.964^{* *} \\
(0.378)\end{array}$ \\
\hline-14 & $\begin{array}{c}-0.393^{* *} \\
(0.177)\end{array}$ & $\begin{array}{r}{ }^{*}-0.235^{*} \\
(0.131)\end{array}$ & $\begin{array}{c}-0.632 \\
(0.387)\end{array}$ & $\begin{array}{c}-0.122 \\
(0.274)\end{array}$ & $\begin{array}{c}-0.241 \\
(0.191)\end{array}$ & $\begin{array}{c}-0.341^{* *} \\
(0.145)\end{array}$ & $\begin{array}{c}0.016 \\
(0.094)\end{array}$ & $\alpha_{3}$ & $\begin{array}{c}-1.616^{* *} \\
(0.727)\end{array}$ & $\begin{array}{c}*-1.194^{* *} \\
(0.532)\end{array}$ & $\begin{array}{l}*-4.333 \\
(2.642)\end{array}$ & $\begin{array}{c}-0.390 \\
(1.679)\end{array}$ & $\begin{array}{c}-1.490^{* *} \\
(0.616)\end{array}$ & $\begin{array}{c}-0.375 \\
(0.449)\end{array}$ & $\begin{array}{r}-0.595^{*} \\
(0.351)\end{array}$ \\
\hline 3 & $\begin{array}{c}-0.439^{* *} \\
(0.179)\end{array}$ & $\begin{array}{r}{ }^{*} 0.284^{*} \\
(0.159)\end{array}$ & $\begin{array}{c}-0.693 \\
(0.478)\end{array}$ & $\begin{array}{c}-0.218 \\
(0.339)\end{array}$ & $\begin{array}{r}-0.075 \\
(0.325)\end{array}$ & $\begin{array}{c}-0.322^{*} \\
(0.185)\end{array}$ & $\begin{array}{c}-0.091 \\
(0.091)\end{array}$ & $\alpha_{4}$ & $\begin{array}{c}-1.950^{* *}= \\
(0.724)\end{array}$ & $\begin{array}{c}*{ }^{*} 1.281^{* *} \\
(0.585)\end{array}$ & $\begin{array}{r}-4.174 \\
(2.629)\end{array}$ & $\begin{array}{l}0.436 \\
(1.864)\end{array}$ & $\begin{array}{c}-0.770 \\
(0.743)\end{array}$ & $\begin{array}{c}0.138 \\
(0.490)\end{array}$ & $\begin{array}{c}-0.589 \\
(0.381)\end{array}$ \\
\hline-12 & $\begin{array}{c}-0.539^{* *} \\
(0.217)\end{array}$ & $\begin{array}{r}{ }^{*} 0.343^{*} \\
(0.179)\end{array}$ & $\begin{array}{c}-0.949^{*} \\
(0.573)\end{array}$ & $\begin{array}{r}-0.287 \\
(0.407)\end{array}$ & $\begin{array}{c}-0.090 \\
(0.259)\end{array}$ & $\begin{array}{c}-0.494^{* * *} \\
(0.191)\end{array}$ & $\begin{array}{r}{ }^{*}-0.061 \\
(0.114)\end{array}$ & $\alpha_{5}$ & $\begin{array}{c}-1.906^{* *}= \\
(0.709)\end{array}$ & $\begin{array}{c}* * 1.434^{* *} \\
(0.555)\end{array}$ & $\begin{array}{r}\text { ** } 4.631^{*} \\
(2.615)\end{array}$ & $\begin{array}{c}-0.006 \\
(1.856)\end{array}$ & $\begin{array}{c}-1.667^{* *} \\
(0.675)\end{array}$ & $\begin{array}{c}0.243 \\
(0.452)\end{array}$ & $\begin{array}{c}-0.916^{* *} \\
(0.363)\end{array}$ \\
\hline-11 & $\begin{array}{c}-0.545^{* *} \\
(0.229)\end{array}$ & $\begin{array}{rl}{ }^{*} & 0.287 \\
& (0.195)\end{array}$ & $\begin{array}{c}-1.116^{*} \\
(0.676)\end{array}$ & $\begin{array}{r}-0.172 \\
(0.487)\end{array}$ & $\begin{array}{c}-0.013 \\
(0.275)\end{array}$ & $\begin{array}{c}-0.653^{* * *} \\
(0.190)\end{array}$ & $\begin{array}{r}{ }^{*}-0.167 \\
(0.119)\end{array}$ & $\alpha_{6}$ & $\begin{array}{c}-2.190^{* *} \\
(0.644)\end{array}$ & $\begin{array}{c}* * 1.702^{* * *} \\
(0.631)\end{array}$ & & $\begin{array}{c}0.584 \\
(2.130)\end{array}$ & & $\begin{array}{c}-0.400 \\
(0.447)\end{array}$ & \\
\hline$x-10$ & $\begin{array}{c}-0.870^{* *} \\
(0.265)\end{array}$ & $\begin{array}{r}{ }^{* * *} 0.676^{* *} \\
(0.198)\end{array}$ & $\begin{array}{l}* * 1.192 \\
(0.725)\end{array}$ & $\begin{array}{c}-0.047 \\
(0.561)\end{array}$ & $\begin{array}{c}-0.290 \\
(0.307)\end{array}$ & $\begin{array}{c}-0.416^{*} \\
(0.231)\end{array}$ & $\begin{array}{c}-0.084 \\
(0.158)\end{array}$ & $\alpha_{7}$ & $\begin{array}{c}-2.012^{* *} \\
(0.768)\end{array}$ & $\begin{array}{c}* * 1.448^{* *} \\
(0.616)\end{array}$ & $\begin{array}{r}{ }^{*}-4.846^{*} \\
(2.581)\end{array}$ & $\begin{array}{c}0.406 \\
(2.065)\end{array}$ & $\begin{array}{c}-2.139^{* * *} \\
(0.734)\end{array}$ & $\begin{array}{c}{ }^{*}-0.663 \\
(0.447)\end{array}$ & $\begin{array}{c}-0.655 \\
(0.401)\end{array}$ \\
\hline$x-9$ & $\begin{array}{c}-0.848^{* *} \\
(0.284)\end{array}$ & $\begin{array}{c}{ }^{* *} 0.737^{* *} \\
(0.200)\end{array}$ & $\begin{array}{l}* 1.285^{*} \\
(0.766)\end{array}$ & $\begin{array}{c}0.220 \\
(0.650)\end{array}$ & $\begin{array}{c}-0.019 \\
(0.342)\end{array}$ & $\begin{array}{c}-0.617^{* * *} \\
(0.222)\end{array}$ & $\begin{array}{c}{ }^{*}-0.297^{* *} \\
(0.138)\end{array}$ & $\alpha_{8}$ & $\begin{array}{c}-2.159^{* *} \\
(0.806)\end{array}$ & $\begin{array}{c}* * 1.780^{* * *} \\
(0.689)\end{array}$ & & $\begin{array}{c}0.218 \\
(2.241)\end{array}$ & & & \\
\hline$\alpha_{-8}$ & $\begin{array}{c}-1.140^{* *} \\
(0.414)\end{array}$ & $\begin{array}{c}{ }^{* * *} 0.718^{* *} \\
(0.304)\end{array}$ & $\begin{array}{c}*-2.315 \\
(1.481)\end{array}$ & $\begin{array}{c}-0.442 \\
(0.546)\end{array}$ & $\begin{array}{l}-1.211^{* * *}- \\
(0.311)\end{array}$ & $\begin{array}{r}{ }^{*}-0.444 \\
(0.350)\end{array}$ & $\begin{array}{r}-0.399^{*} \\
(0.204)\end{array}$ & $\alpha_{9}$ & $\begin{array}{c}-2.225^{* *} \\
(0.755)\end{array}$ & $\begin{array}{c}* * 1.490^{* *} \\
(0.669)\end{array}$ & $\begin{array}{c}{ }^{*}-4.764^{* *} \\
(2.405)\end{array}$ & $* \begin{array}{c}0.060 \\
(2.251)\end{array}$ & $\begin{array}{c}-2.076^{* *} \\
(0.818)\end{array}$ & $\begin{array}{c}-0.094 \\
(0.520)\end{array}$ & $\begin{array}{c}-1.011^{* *} \\
(0.425)\end{array}$ \\
\hline$\alpha_{-7}$ & $\begin{array}{c}-1.084^{* *} \\
(0.445)\end{array}$ & $\begin{array}{r}{ }^{*}-0.802^{* *} \\
(0.340)\end{array}$ & $\begin{array}{c}*-2.544 \\
(1.563)\end{array}$ & $\begin{array}{c}-0.281 \\
(0.602)\end{array}$ & $\begin{array}{c}-1.452^{* * *} \\
(0.364)\end{array}$ & $\begin{array}{c}*-0.487^{*} \\
(0.268)\end{array}$ & $\begin{array}{c}-0.542^{* *} \\
(0.218)\end{array}$ & $\alpha_{10}$ & $\begin{array}{c}-2.786^{* *} \\
(0.960)\end{array}$ & $\begin{array}{c}\text { ** } 1.158^{* *} \\
(0.548)\end{array}$ & $\begin{array}{c}-4.958 \\
(3.266)\end{array}$ & $\begin{array}{c}0.330 \\
(1.655)\end{array}$ & $\begin{array}{c}-0.081 \\
(0.852)\end{array}$ & $\begin{array}{c}-0.165 \\
(0.706)\end{array}$ & \\
\hline$\alpha_{-6}$ & $\begin{array}{c}-1.312^{* *} \\
(0.508)\end{array}$ & $\begin{array}{r}\text { *** }^{*} 0.932^{* * *} \\
(0.375)\end{array}$ & $\begin{array}{c}* 2.544 \\
(1.630)\end{array}$ & $\begin{array}{c}-0.255 \\
(0.668)\end{array}$ & $\begin{array}{c}-1.459^{* * *} \\
(0.383)\end{array}$ & $\begin{array}{r}* 0.713^{*} \\
(0.365)\end{array}$ & $\begin{array}{c}-0.629^{* *} \\
(0.253)\end{array}$ & $\alpha_{11}$ & $\begin{array}{c}-2.623^{* *} \\
(1.062)\end{array}$ & $\begin{array}{c}*-0.743 \\
(0.505)\end{array}$ & $\begin{array}{c}-4.580 \\
(3.196)\end{array}$ & $\begin{array}{c}0.072 \\
(1.815)\end{array}$ & $\begin{array}{c}-0.534 \\
(0.843)\end{array}$ & $\begin{array}{c}0.710 \\
(0.651)\end{array}$ & $\begin{array}{c}-0.741 \\
(0.522)\end{array}$ \\
\hline$\alpha_{-5}$ & $\begin{array}{c}-1.316^{* *} \\
(0.552)\end{array}$ & $\begin{array}{r}{ }^{*}-0.768^{* *} \\
(0.366)\end{array}$ & $\begin{array}{r}*-2.830^{*} \\
(1.664)\end{array}$ & $\begin{array}{c}0.071 \\
(0.786)\end{array}$ & $\begin{array}{c}-1.667^{* * *} \\
(0.368)\end{array}$ & $\begin{array}{c}*-0.493 \\
(0.365)\end{array}$ & $\begin{array}{c}-0.736^{* * *} \\
(0.251)\end{array}$ & $\alpha_{12}$ & $\begin{array}{c}-2.926^{* *}= \\
(1.134)\end{array}$ & $\begin{array}{c}* * 1.482^{* *} \\
(0.631)\end{array}$ & & $\begin{array}{c}0.162 \\
(1.813)\end{array}$ & $\begin{array}{c}-0.606 \\
(0.930)\end{array}$ & $\begin{array}{c}0.110 \\
(0.794)\end{array}$ & $\begin{array}{c}-0.773 \\
(0.569)\end{array}$ \\
\hline$\alpha_{-4}$ & $\begin{array}{c}-1.206^{* *} \\
(0.578)\end{array}$ & $\begin{array}{r}{ }^{*}-0.796^{* *} \\
(0.377)\end{array}$ & $\begin{array}{c}*-2.531 \\
(1.702)\end{array}$ & $\begin{array}{c}0.365 \\
(0.854)\end{array}$ & $\begin{array}{l}-1.063^{* * *} \\
(0.396)\end{array}$ & $\begin{array}{c}*-0.587^{*} \\
(0.351)\end{array}$ & $\begin{array}{c}-0.565^{* *} \\
(0.236)\end{array}$ & $\alpha_{13}$ & $\begin{array}{c}-2.955^{* *} \\
(1.033)\end{array}$ & & & & & $\begin{array}{ll}39 & - \\
58)\end{array}$ & $\begin{array}{c}-1.189^{* *} \\
(0.547)\end{array}$ \\
\hline$\alpha_{-3}$ & $\begin{array}{c}-1.370^{* *} \\
(0.569)\end{array}$ & $\begin{array}{r}{ }^{*}-0.767^{*} \\
(0.430)\end{array}$ & $\begin{array}{c}-2.909^{*} \\
(1.698)\end{array}$ & $\begin{array}{c}-0.152 \\
(0.927)\end{array}$ & $\begin{array}{l}-1.439^{* * *} \\
(0.421)\end{array}$ & $\begin{array}{c}*-0.742^{* *}- \\
(0.328)\end{array}$ & $\begin{array}{c}-0.624^{* *} \\
(0.275)\end{array}$ & $\alpha_{14}$ & $\begin{array}{c}-3.441^{* *} \\
(1.219)\end{array}$ & $\begin{array}{c}* * 1.643^{* *} \\
(0.669)\end{array}$ & $\begin{array}{r}-4.797 \\
(3.019)\end{array}$ & $\begin{array}{l}1.096 \\
(1.998)\end{array}$ & & $\begin{array}{c}0.195 \\
(0.787)\end{array}$ & \\
\hline$\alpha_{-2}$ & $\begin{array}{c}-1.422^{* *} \\
(0.502)\end{array}$ & $\begin{array}{r}\text { *** }^{*} .014^{* * *} \\
(0.421)\end{array}$ & $\begin{array}{r}*-2.918 * \\
(1.698)\end{array}$ & $\begin{array}{c}0.341 \\
(1.048)\end{array}$ & $\begin{array}{l}-1.646^{* * *}- \\
(0.443)\end{array}$ & $\begin{array}{c}*-0.796^{* *}- \\
(0.360)\end{array}$ & $\begin{array}{c}-0.687^{* *} \\
(0.288)\end{array}$ & $\alpha_{15}$ & $\begin{array}{c}-3.221^{* *} \\
(1.266)\end{array}$ & & & & & & \\
\hline$\alpha_{-1}$ & $\begin{array}{c}-1.514^{* *} \\
(0.589)\end{array}$ & $\begin{array}{r}{ }^{*}-0.912^{*} \\
(0.466)\end{array}$ & $\begin{array}{r}-3.203^{*} \\
(1.687)\end{array}$ & $\begin{array}{c}0.542 \\
(1.132)\end{array}$ & $\begin{array}{c}-0.705 \\
(0.669)\end{array}$ & $\begin{array}{c}-0.661^{*} \\
(0.369)\end{array}$ & $\begin{array}{c}-0.563^{* *} \\
(0.269)\end{array}$ & $\alpha_{16}$ & $\begin{array}{c}-3.279^{* *} \\
(1.230)\end{array}$ & $\begin{array}{c}* * 1.690^{* * *} \\
(0.647)\end{array}$ & $\begin{array}{r}* 4.585^{*} \\
(2.777)\end{array}$ & $\begin{array}{l}1.210 \\
(2.142)\end{array}$ & $\begin{array}{r}-0 . \\
(1 .\end{array}$ & $\begin{array}{c}-0.145 \\
(0.783)\end{array}$ & $\begin{array}{l}88^{*} \\
83)\end{array}$ \\
\hline$\alpha_{0}$ & $\begin{array}{l}3.401^{* *} \\
(1.298)\end{array}$ & $\begin{array}{l}{ }^{* *} 2.821^{* *} \\
(0.481)\end{array}$ & $\begin{array}{l}* * 0.838 \\
(0.985)\end{array}$ & $\begin{array}{l}7.049^{* *} \\
(3.262)\end{array}$ & $\begin{array}{l}1.673^{* * *} \\
(0.503)\end{array}$ & $\begin{array}{l}* 1.821^{* * *} \\
(0.377)\end{array}$ & $\begin{array}{l}* 1.740^{* * *} \\
(0.314)\end{array}$ & $\alpha_{17}$ & $\begin{array}{c}-3.374^{* *} \\
(1.038)\end{array}$ & $\begin{array}{r}* * 1.7 \\
* 0.6\end{array}$ & $\begin{array}{r}{ }^{*}-5.011^{*} \\
(2.674)\end{array}$ & $\begin{array}{c}2.069 \\
(2.862)\end{array}$ & & $\begin{array}{c}-0.180 \\
(0.854)\end{array}$ & $\begin{array}{r}-1 \\
(0 .\end{array}$ \\
\hline Lag $\mathrm{C}$ & & (gin & & & & & & & $\begin{array}{c}0.034^{*} \\
(0.021)\end{array}$ & $(0.015)$ & $\begin{array}{c}{ }^{k *} 0.041 \\
(0.097)\end{array}$ & $\begin{array}{c}-0.012 \\
(0.061)\end{array}$ & $\begin{array}{c}0.024 \\
(0.018)\end{array}$ & $\begin{array}{l}0.074^{* * *} \\
(0.021)\end{array}$ & $\begin{array}{c}* \begin{array}{c}0.015 \\
(0.025)\end{array}\end{array}$ \\
\hline $\begin{array}{l}\text { Lag } \\
\text { wit }\end{array}$ & in 45 & ive & He lited & hold $\mathrm{C}$ & $\left(\beta_{1}\right)$ & & & & $\begin{array}{c}0.012 \\
(0.011)\end{array}$ & $\begin{array}{c}0.004 \\
(0.007)\end{array}$ & $\begin{array}{c}0.035 \\
(0.026)\end{array}$ & $\begin{array}{l}0.015 \\
(0.018)\end{array}$ & $\begin{array}{l}0.021^{* *} \\
(0.009)\end{array}$ & $\begin{array}{c}-0.007 \\
(0.009)\end{array}$ & $\begin{array}{c}0.020^{* *} \\
(0.010)\end{array}$ \\
\hline & $\begin{array}{l}\text { cumula } \\
\text { in } 45 \mathrm{~m}\end{array}$ & ive sign- & 1ps * & 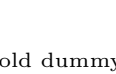 & $\left.3_{2}\right)$ & & & & $\begin{array}{l}0.009 \\
(0.016)\end{array}$ & $\begin{array}{c}-0.002 \\
(0.008)\end{array}$ & $\begin{array}{c}0.048 \\
(0.049)\end{array}$ & $\begin{array}{c}0.032 \\
(0.041)\end{array}$ & $\begin{array}{c}0.018 \\
(0.013)\end{array}$ & $\begin{array}{c}-0.023^{* *} \\
(0.011)\end{array}$ & $\begin{array}{c}0.018 \\
(0.015)\end{array}$ \\
\hline $\begin{array}{l}\text { Lag } \\
\text { from }\end{array}$ & $\begin{array}{l}\text { cumulat } \\
45 \mathrm{~min}\end{array}$ & ive sign- & ps * & $d_{1}$ & ld & ny & & & $\begin{array}{l}0.015 \\
(0.020)\end{array}$ & $\begin{array}{c}-0.010 \\
(0.008)\end{array}$ & $\begin{array}{c}0.048 \\
(0.059)\end{array}$ & $\begin{array}{c}0.036 \\
(0.043)\end{array}$ & $\begin{array}{c}0.007 \\
(0.012)\end{array}$ & $\begin{array}{c}-0.028^{*} \\
(0.015)\end{array}$ & $\begin{array}{c}0.018 \\
(0.019)\end{array}$ \\
\hline & e-of-t & & & & & & & & & & & & & & Yes \\
\hline & $\mathrm{fi}$ & & & & & & & & & & & & & & Yes \\
\hline Num & aber o & 促 & & & & & & & 11,514 & 15,894 & 22,399 & 12,956 & 10,670 & 13,702 & 14,309 \\
\hline Num & aber of de & eals & & & & & & & 340 & 468 & 660 & 382 & 314 & 403 & 421 \\
\hline
\end{tabular}

Note: Dependent variable is the number of new sign-ups per 5-min time interval. Standard errors are clustered by deal and reported in parentheses. ${ }^{* * *} p<0.01,{ }^{* *} p<0.05,{ }^{*} p<0.1$. 
Table A2 Population-categorized Regression Results from Three-hour Data using GMM Estimator with 2 Lags.

\begin{tabular}{|c|c|c|c|c|c|c|c|c|c|}
\hline & $<0.25 \mathrm{mil}$ & $0.25-0.5 \mathrm{mil}$ & $0.5-1 \mathrm{mil}$ & $>1 \mathrm{mil}$ & & $<0.25 \mathrm{mil}$ & $0.25-0.5 \mathrm{mil}$ & $0.5-1 \mathrm{mil}$ & $>1 \mathrm{mil}$ \\
\hline$\alpha_{-16}$ & $\begin{array}{c}-0.118^{*} \\
(0.060)\end{array}$ & $\begin{array}{c}-0.156^{* *} \\
(0.063)\end{array}$ & $\begin{array}{c}-0.040 \\
(0.068)\end{array}$ & $\begin{array}{c}-0.185 \\
(0.146)\end{array}$ & $\alpha_{1}$ & $\begin{array}{c}0.506 \\
(0.451)\end{array}$ & $\begin{array}{c}-0.476^{* *} \\
(0.216)\end{array}$ & $\begin{array}{c}-2.783^{* * *} \\
(0.989)\end{array}$ & $\begin{array}{c}-1.372 \\
(0.878)\end{array}$ \\
\hline$\alpha-15$ & $\begin{array}{c}-0.127^{*} \\
(0.065)\end{array}$ & $\begin{array}{c}-0.231^{* * *} \\
(0.067)\end{array}$ & $\begin{array}{c}-0.260^{* * *} \\
(0.093)\end{array}$ & $\begin{array}{r}-0.016 \\
(0.177)\end{array}$ & $\alpha_{2}$ & $\begin{array}{c}0.225 \\
(0.462)\end{array}$ & $\begin{array}{c}-0.757^{* * *} \\
(0.223)\end{array}$ & $\begin{array}{c}-3.389^{* * *} \\
(1.092)\end{array}$ & $\begin{array}{c}-1.243 \\
(1.076)\end{array}$ \\
\hline$\alpha-14$ & $\begin{array}{c}-0.195^{* * *} \\
(0.070)\end{array}$ & $\begin{array}{c}-0.207^{* * *} \\
(0.075)\end{array}$ & $\begin{array}{c}-0.409^{* * *} \\
(0.123)\end{array}$ & $\begin{array}{c}-0.372^{*} \\
(0.203)\end{array}$ & $\alpha_{3}$ & $\begin{array}{c}0.174 \\
(0.456)\end{array}$ & $\begin{array}{c}-0.625^{* *} \\
(0.245)\end{array}$ & $\begin{array}{c}-3.124^{* * *} \\
(1.145)\end{array}$ & $\begin{array}{r}-1.503 \\
(0.982)\end{array}$ \\
\hline$\alpha-13$ & $\begin{array}{c}-0.100 \\
(0.083)\end{array}$ & $\begin{array}{c}-0.280^{* * *} \\
(0.079)\end{array}$ & $\begin{array}{c}-0.536^{* * *} \\
(0.159)\end{array}$ & $\begin{array}{c}-0.456^{* *} \\
(0.228)\end{array}$ & $\alpha_{4}$ & $\begin{array}{c}0.252 \\
(0.507)\end{array}$ & $\begin{array}{c}-0.399 \\
(0.280)\end{array}$ & $\begin{array}{c}-3.067^{* * *} \\
(1.144)\end{array}$ & $\begin{array}{c}-1.106 \\
(1.001)\end{array}$ \\
\hline$\alpha-12$ & $\begin{array}{c}-0.086 \\
(0.094)\end{array}$ & $\begin{array}{c}-0.149 \\
(0.097)\end{array}$ & $\begin{array}{c}-0.777^{* * *} \\
(0.173)\end{array}$ & $\begin{array}{c}-0.658^{* *} \\
(0.279)\end{array}$ & $\alpha_{5}$ & $\begin{array}{c}0.145 \\
(0.468)\end{array}$ & $\begin{array}{c}-0.714^{* * *} \\
(0.275)\end{array}$ & $\begin{array}{c}-3.491^{* * *} \\
(1.125)\end{array}$ & $\begin{array}{c}-1.568 \\
(1.018)\end{array}$ \\
\hline$\alpha-11$ & $\begin{array}{c}-0.106 \\
(0.103)\end{array}$ & $\begin{array}{c}-0.327^{* * *} \\
(0.112)\end{array}$ & $\begin{array}{c}-0.856^{* * *} \\
(0.196)\end{array}$ & $\begin{array}{c}-0.378 \\
(0.323)\end{array}$ & $\alpha_{6}$ & $\begin{array}{c}0.076 \\
(0.474)\end{array}$ & $\begin{array}{c}-0.747^{* * *} \\
(0.280)\end{array}$ & $\begin{array}{c}-3.780^{* * *} \\
(1.074)\end{array}$ & $\begin{array}{c}-1.715 \\
(1.221)\end{array}$ \\
\hline$\alpha_{-10}$ & $\begin{array}{c}-0.108 \\
(0.113)\end{array}$ & $\begin{array}{c}-0.371^{* * *} \\
(0.115)\end{array}$ & $\begin{array}{c}-0.954^{* * *} \\
(0.213)\end{array}$ & $\begin{array}{c}-0.799^{* *} \\
(0.356)\end{array}$ & $\alpha_{7}$ & $\begin{array}{r}-0.185 \\
(0.463)\end{array}$ & $\begin{array}{c}-0.646^{* *} \\
(0.325)\end{array}$ & $\begin{array}{c}-3.602^{* * *} \\
(1.122)\end{array}$ & $\begin{array}{c}-1.879^{*} \\
(1.081)\end{array}$ \\
\hline$\alpha_{-9}$ & $\begin{array}{r}-0.130 \\
(0.117)\end{array}$ & $\begin{array}{c}-0.313^{* *} \\
(0.128)\end{array}$ & $\begin{array}{c}-1.052^{* * *} \\
(0.228)\end{array}$ & $\begin{array}{c}-0.937^{* *} \\
(0.380)\end{array}$ & $\alpha_{8}$ & $\begin{array}{c}0.166 \\
(0.490)\end{array}$ & $\begin{array}{c}-0.751^{* *} \\
(0.322)\end{array}$ & $\begin{array}{c}-3.493^{* * *} \\
(1.121)\end{array}$ & $\begin{array}{c}-1.808 \\
(1.117)\end{array}$ \\
\hline$\alpha_{-8}$ & $\begin{array}{c}0.081 \\
(0.193)\end{array}$ & $\begin{array}{c}-0.362^{* *} \\
(0.162)\end{array}$ & $\begin{array}{c}-1.757^{* * *} \\
(0.627)\end{array}$ & $\begin{array}{c}-0.938^{*} \\
(0.548)\end{array}$ & $\alpha_{9}$ & $\begin{array}{r}-0.130 \\
(0.455)\end{array}$ & $\begin{array}{c}-0.686^{* *} \\
(0.334)\end{array}$ & $\begin{array}{c}-3.608^{* * *} \\
(1.137)\end{array}$ & $\begin{array}{c}-2.180^{*} \\
(1.150)\end{array}$ \\
\hline$\alpha_{-7}$ & $\begin{array}{c}0.122 \\
(0.191)\end{array}$ & $\begin{array}{c}-0.538^{* * *} \\
(0.184)\end{array}$ & $\begin{array}{c}-1.908^{* * *} \\
(0.637)\end{array}$ & $\begin{array}{c}-0.889 \\
(0.586)\end{array}$ & $\alpha_{10}$ & $\begin{array}{c}0.609 \\
(0.494)\end{array}$ & $\begin{array}{r}-0.457 \\
(0.354)\end{array}$ & $\begin{array}{c}-3.298^{* * *} \\
(1.264)\end{array}$ & $\begin{array}{c}-1.373 \\
(1.111)\end{array}$ \\
\hline$\alpha_{-6}$ & $\begin{array}{c}0.076 \\
(0.210)\end{array}$ & $\begin{array}{c}-0.489^{* *} \\
(0.196)\end{array}$ & $\begin{array}{c}-2.031^{* * *} \\
(0.644)\end{array}$ & $\begin{array}{r}-0.988 \\
(0.648)\end{array}$ & $\alpha_{11}$ & $\begin{array}{c}0.332 \\
(0.516)\end{array}$ & $\begin{array}{c}-0.446 \\
(0.352)\end{array}$ & $\begin{array}{c}-3.112^{* *} \\
(1.244)\end{array}$ & $\begin{array}{c}-0.851 \\
(1.159)\end{array}$ \\
\hline$\alpha_{-5}$ & $\begin{array}{c}0.108 \\
(0.227)\end{array}$ & $\begin{array}{c}-0.508^{* *} \\
(0.199)\end{array}$ & $\begin{array}{c}-1.898^{* * *} \\
(0.633)\end{array}$ & $\begin{array}{c}-1.506^{* *} \\
(0.665)\end{array}$ & $\alpha_{12}$ & $\begin{array}{c}0.371 \\
(0.480)\end{array}$ & $\begin{array}{r}-0.459 \\
(0.395)\end{array}$ & $\begin{array}{c}-3.148^{* *} \\
(1.226)\end{array}$ & $\begin{array}{c}-1.384 \\
(1.192)\end{array}$ \\
\hline$\alpha_{-4}$ & $\begin{array}{c}0.141 \\
(0.211)\end{array}$ & $\begin{array}{c}-0.371^{*} \\
(0.193)\end{array}$ & $\begin{array}{c}-1.825^{* * *} \\
(0.610)\end{array}$ & $\begin{array}{c}-0.690 \\
(0.702)\end{array}$ & $\alpha_{13}$ & $\begin{array}{c}0.301 \\
(0.462)\end{array}$ & $\begin{array}{r}-0.543 \\
(0.385)\end{array}$ & $\begin{array}{c}-3.353^{* * *} \\
(1.138)\end{array}$ & $\begin{array}{c}-1.609 \\
(1.182)\end{array}$ \\
\hline$\alpha-3$ & $\begin{array}{c}0.114 \\
(0.209)\end{array}$ & $\begin{array}{c}-0.594^{* * *} \\
(0.222)\end{array}$ & $\begin{array}{c}-2.140^{* * *} \\
(0.573)\end{array}$ & $\begin{array}{c}-1.337^{*} \\
(0.749)\end{array}$ & $\alpha_{14}$ & $\begin{array}{c}0.320 \\
(0.502)\end{array}$ & $\begin{array}{c}-0.633^{*} \\
(0.370)\end{array}$ & $\begin{array}{c}-3.181^{* * *} \\
(1.105)\end{array}$ & $\begin{array}{c}-1.765 \\
(1.248)\end{array}$ \\
\hline$\alpha-2$ & $\begin{array}{c}0.122 \\
(0.219)\end{array}$ & $\begin{array}{c}-0.664^{* * *} \\
(0.216)\end{array}$ & $\begin{array}{c}-2.176^{* * *} \\
(0.541)\end{array}$ & $\begin{array}{c}-1.320^{*} \\
(0.752)\end{array}$ & $\alpha_{15}$ & $\begin{array}{c}0.001 \\
(0.438)\end{array}$ & $\begin{array}{r}-0.627 \\
(0.402)\end{array}$ & $\begin{array}{c}-3.139^{* * *} \\
(1.087)\end{array}$ & $\begin{array}{c}-1.606 \\
(1.287)\end{array}$ \\
\hline$\alpha-1$ & $\begin{array}{c}0.039 \\
(0.206)\end{array}$ & $\begin{array}{c}-0.559^{* *} \\
(0.223)\end{array}$ & $\begin{array}{c}-1.903^{* * *} \\
(0.485)\end{array}$ & $\begin{array}{c}-1.260 \\
(0.820)\end{array}$ & $\alpha_{16}$ & $\begin{array}{c}-0.035 \\
(0.466)\end{array}$ & $\begin{array}{c}-0.592 \\
(0.463)\end{array}$ & $\begin{array}{c}-3.258^{* * *} \\
(1.049)\end{array}$ & $\begin{array}{c}-1.677 \\
(1.275)\end{array}$ \\
\hline$\alpha_{0}$ & $\begin{array}{l}3.392^{* * *} \\
(0.509)\end{array}$ & $\begin{array}{l}2.603^{* * *} \\
(0.259)\end{array}$ & $\begin{array}{l}1.266^{* * *} \\
(0.383)\end{array}$ & $\begin{array}{c}3.279^{*} \\
(1.888)\end{array}$ & $\alpha_{17}$ & $\begin{array}{c}-0.022 \\
(0.448)\end{array}$ & $\begin{array}{c}-1.059^{* * *} \\
(0.390)\end{array}$ & $\begin{array}{c}-3.365^{* * *} \\
(0.963)\end{array}$ & $\begin{array}{c}-1.518 \\
(1.807)\end{array}$ \\
\hline \multicolumn{6}{|c|}{ Lag cumulative sign-ups } & $\begin{array}{l}0.116^{* * *} \\
(0.035)\end{array}$ & $\begin{array}{l}0.056^{* * *} \\
(0.017)\end{array}$ & $\begin{array}{c}0.001 \\
(0.060)\end{array}$ & $\begin{array}{l}0.066^{* * *} \\
(0.012)\end{array}$ \\
\hline \multicolumn{6}{|c|}{ Lag cumulative sign-ups $*$} & $\begin{array}{c}-0.010 \\
(0.009)\end{array}$ & $\begin{array}{c}0.003 \\
(0.009)\end{array}$ & $\begin{array}{c}0.021 \\
(0.015)\end{array}$ & $\begin{array}{c}0.002 \\
(0.005)\end{array}$ \\
\hline \multicolumn{6}{|c|}{ Lag cumulative sign-ups $*$} & $\begin{array}{c}-0.029 \\
(0.020)\end{array}$ & $\begin{array}{c}-0.005 \\
(0.009)\end{array}$ & $\begin{array}{c}0.034 \\
(0.030)\end{array}$ & $\begin{array}{r}-0.010 \\
(0.007)\end{array}$ \\
\hline \multicolumn{4}{|c|}{ Lag cumulative sign-ups $*$} & \multicolumn{2}{|c|}{ from 45 minutes to 90 minutes after threshold dummy $\left(\beta_{3}\right)$} & $\begin{array}{c}-0.040^{*} \\
(0.021)\end{array}$ & $\begin{array}{r}-0.012 \\
(0.013)\end{array}$ & $\begin{array}{c}0.028 \\
(0.037)\end{array}$ & $\begin{array}{c}-0.016^{* *} \\
(0.008)\end{array}$ \\
\hline \multicolumn{6}{|c|}{ Time-of-the-day fixed effects } & Yes & Yes & Yes & Yes \\
\hline \multicolumn{6}{|c|}{ Deal fixed effects } & Yes & Yes & Yes & Yes \\
\hline \multicolumn{6}{|c|}{ Number of observations } & 33,545 & 33,003 & 53,057 & 23,299 \\
\hline \multicolumn{6}{|c|}{ Number of deals } & 988 & 972 & 1,562 & 686 \\
\hline
\end{tabular}

Note: Dependent variable is the number of new sign-ups per 5-min time interval. Standard errors are clustered by deal and reported in parentheses. ${ }^{* * *} p<0.01,{ }^{* *} p<0.05,{ }^{*} p<0.1$. 
Table A3 Regional Level Regression Results from Three-hour Data using GMM Estimator with 2 Lags.

\begin{tabular}{|c|c|c|c|c|c|c|c|c|c|c|c|}
\hline & West & Midwest & South & Northeast & Canada & & West & Midwest & South & Northeast & Canada \\
\hline$\alpha_{-16}$ & $\begin{array}{c}-0.190 * * \\
(0.076)\end{array}$ & $\begin{array}{r}-0.173 \\
(0.109)\end{array}$ & $\begin{array}{r}-0.048 \\
(0.081)\end{array}$ & $\begin{array}{r}-0.143 \\
(0.099)\end{array}$ & $\begin{array}{c}0.051 \\
(0.117)\end{array}$ & $\alpha_{1}$ & $\begin{array}{c}-1.160^{* * *} \\
(0.446)\end{array}$ & $\begin{array}{c}-0.567 \\
(1.076)\end{array}$ & $\begin{array}{r}-1.066 \\
(1.429)\end{array}$ & $\begin{array}{c}-1.843^{* * *} \\
(0.640)\end{array}$ & $\begin{array}{c}-1.084^{* *} \\
(0.534)\end{array}$ \\
\hline$\alpha-15$ & $\begin{array}{c}-0.188^{* *} \\
(0.088)\end{array}$ & $\begin{array}{c}-0.305^{*} \\
(0.161)\end{array}$ & $\begin{array}{r}-0.153 \\
(0.122)\end{array}$ & $\begin{array}{c}-0.245^{* *} \\
(0.119)\end{array}$ & $\begin{array}{c}0.136 \\
(0.127)\end{array}$ & $\alpha_{2}$ & $\begin{array}{c}-1.457^{* * *} \\
(0.464)\end{array}$ & $\begin{array}{c}-1.407 \\
(1.364)\end{array}$ & $\begin{array}{r}-1.160 \\
(1.480)\end{array}$ & $\begin{array}{c}-2.096^{* * *} \\
(0.628)\end{array}$ & $\begin{array}{c}-1.099^{* *} \\
(0.498)\end{array}$ \\
\hline$\alpha-14$ & $\begin{array}{c}-0.294^{* * *} \\
(0.103)\end{array}$ & $\begin{array}{c}-0.526^{* *} \\
(0.210)\end{array}$ & $\begin{array}{r}-0.163 \\
(0.166)\end{array}$ & $\begin{array}{c}-0.478^{* * *} \\
(0.130)\end{array}$ & $\begin{array}{r}-0.053 \\
(0.138)\end{array}$ & $\alpha_{3}$ & $\begin{array}{c}-1.279^{* * *} \\
(0.474)\end{array}$ & $\begin{array}{c}-1.346 \\
(1.392)\end{array}$ & $\begin{array}{r}-1.111 \\
(1.529)\end{array}$ & $\begin{array}{c}-2.014^{* * *} \\
(0.679)\end{array}$ & $\begin{array}{c}-1.135^{* *} \\
(0.553)\end{array}$ \\
\hline$\alpha-13$ & $\begin{array}{c}-0.269^{* *} \\
(0.128)\end{array}$ & $\begin{array}{c}-0.629^{* *} \\
(0.253)\end{array}$ & $\begin{array}{r}-0.264 \\
(0.211)\end{array}$ & $\begin{array}{c}-0.556^{* * *} \\
(0.157)\end{array}$ & $\begin{array}{c}0.085 \\
(0.141)\end{array}$ & $\alpha_{4}$ & $\begin{array}{c}-1.167^{* *} \\
(0.485)\end{array}$ & $\begin{array}{c}-0.901 \\
(1.409)\end{array}$ & $\begin{array}{c}-0.923 \\
(1.585)\end{array}$ & $\begin{array}{c}-2.143^{* * *} \\
(0.714)\end{array}$ & $\begin{array}{c}-1.045^{*} \\
(0.582)\end{array}$ \\
\hline$\alpha-12$ & $\begin{array}{c}-0.410^{* * *} \\
(0.138)\end{array}$ & $\begin{array}{c}-0.681^{* *} \\
(0.299)\end{array}$ & $\begin{array}{c}-0.327 \\
(0.255)\end{array}$ & $\begin{array}{c}-0.682^{* * *} \\
(0.192)\end{array}$ & $\begin{array}{c}0.018 \\
(0.159)\end{array}$ & $\alpha_{5}$ & $\begin{array}{c}-1.441^{* * *} \\
(0.512)\end{array}$ & $\begin{array}{c}-1.248 \\
(1.359)\end{array}$ & $\begin{array}{r}-1.413 \\
(1.629)\end{array}$ & $\begin{array}{c}-2.275^{* * *} \\
(0.748)\end{array}$ & $\begin{array}{c}-1.099^{*} \\
(0.572)\end{array}$ \\
\hline$\alpha-11$ & $\begin{array}{c}-0.300^{*} \\
(0.168)\end{array}$ & $\begin{array}{c}-0.757^{* *} \\
(0.343)\end{array}$ & $\begin{array}{r}-0.371 \\
(0.293)\end{array}$ & $\begin{array}{c}-0.879^{* * *} \\
(0.226)\end{array}$ & $\begin{array}{c}0.002 \\
(0.202)\end{array}$ & $\alpha_{6}$ & $\begin{array}{c}-1.799^{* * *} \\
(0.522)\end{array}$ & $\begin{array}{c}-1.293 \\
(1.348)\end{array}$ & $\begin{array}{r}-1.431 \\
(1.709)\end{array}$ & $\begin{array}{c}-2.562^{* * *} \\
(0.685)\end{array}$ & $\begin{array}{c}-1.184^{* *} \\
(0.519)\end{array}$ \\
\hline$\alpha-10$ & $\begin{array}{c}-0.601^{* * *} \\
(0.165)\end{array}$ & $\begin{array}{c}-0.838^{* *} \\
(0.353)\end{array}$ & $\begin{array}{r}-0.379 \\
(0.346)\end{array}$ & $\begin{array}{c}-0.962^{* * *} \\
(0.258)\end{array}$ & $\begin{array}{r}-0.129 \\
(0.209)\end{array}$ & $\alpha_{7}$ & $\begin{array}{c}-1.615^{* * *} \\
(0.543)\end{array}$ & $\begin{array}{c}-1.181 \\
(1.333)\end{array}$ & $\begin{array}{r}-1.440 \\
(1.724)\end{array}$ & $\begin{array}{c}-3.045^{* * *} \\
(0.830)\end{array}$ & $\begin{array}{r}-1.024^{*} \\
(0.564)\end{array}$ \\
\hline$\alpha-9$ & $\begin{array}{c}-0.541^{* * *} \\
(0.201)\end{array}$ & $\begin{array}{c}-0.813^{* *} \\
(0.375)\end{array}$ & $\begin{array}{r}-0.490 \\
(0.375)\end{array}$ & $\begin{array}{c}-1.235^{* * *} \\
(0.294)\end{array}$ & $\begin{array}{c}0.186 \\
(0.252)\end{array}$ & $\alpha_{8}$ & $\begin{array}{c}-1.585^{* * *} \\
(0.569)\end{array}$ & $\begin{array}{c}-0.931 \\
(1.243)\end{array}$ & $\begin{array}{r}-1.518 \\
(1.792)\end{array}$ & $\begin{array}{c}-2.557^{* * *} \\
(0.848)\end{array}$ & $\begin{array}{c}-0.955^{*} \\
(0.565)\end{array}$ \\
\hline$\alpha_{-8}$ & $\begin{array}{c}-0.765^{* * *} \\
(0.248)\end{array}$ & $\begin{array}{r}-1.134 \\
(0.874)\end{array}$ & $\begin{array}{r}-0.569 \\
(0.517)\end{array}$ & $\begin{array}{c}-1.216^{* * *} \\
(0.401)\end{array}$ & $\begin{array}{c}-0.733^{* * *} \\
(0.282)\end{array}$ & $\alpha_{9}$ & $\begin{array}{c}-1.657^{* * *} \\
(0.559)\end{array}$ & $\begin{array}{c}-1.051 \\
(1.235)\end{array}$ & $\begin{array}{r}-1.740 \\
(1.832)\end{array}$ & $\begin{array}{c}-2.789^{* * *} \\
(0.831)\end{array}$ & $\begin{array}{r}-0.901 \\
(0.617)\end{array}$ \\
\hline$\alpha_{-7}$ & $\begin{array}{c}-0.642^{* *} \\
(0.257)\end{array}$ & $\begin{array}{r}-1.381 \\
(0.899)\end{array}$ & $\begin{array}{r}-0.714 \\
(0.552)\end{array}$ & $\begin{array}{c}-1.178^{* * *} \\
(0.419)\end{array}$ & $\begin{array}{c}-0.784^{* *} \\
(0.309)\end{array}$ & $\alpha_{10}$ & $\begin{array}{c}-1.225^{* *} \\
(0.577)\end{array}$ & $\begin{array}{c}-0.456 \\
(1.626)\end{array}$ & $\begin{array}{c}-0.909 \\
(1.487)\end{array}$ & $\begin{array}{c}-2.194^{* * *} \\
(0.793)\end{array}$ & $\begin{array}{c}-1.867^{* * *} \\
(0.612)\end{array}$ \\
\hline$\alpha-6$ & $\begin{array}{c}-0.605^{* *} \\
(0.270)\end{array}$ & $\begin{array}{r}-1.346 \\
(0.954)\end{array}$ & $\begin{array}{r}-0.803 \\
(0.600)\end{array}$ & $\begin{array}{c}-1.592^{* * *} \\
(0.455)\end{array}$ & $\begin{array}{c}-0.739^{* *} \\
(0.330)\end{array}$ & $\alpha_{11}$ & $\begin{array}{r}-0.935 \\
(0.585)\end{array}$ & $\begin{array}{c}-0.318 \\
(1.622)\end{array}$ & $\begin{array}{c}-0.844 \\
(1.556)\end{array}$ & $\begin{array}{c}-2.543^{* * *} \\
(0.866)\end{array}$ & $\begin{array}{c}-1.330^{*} \\
(0.713)\end{array}$ \\
\hline$\alpha_{-5}$ & $\begin{array}{c}-0.608^{* *} \\
(0.285)\end{array}$ & $\begin{array}{r}-1.477 \\
(0.993)\end{array}$ & $\begin{array}{r}-0.830 \\
(0.618)\end{array}$ & $\begin{array}{c}-1.646^{* * *} \\
(0.483)\end{array}$ & $\begin{array}{r}-0.384 \\
(0.299)\end{array}$ & $\alpha_{12}$ & $\begin{array}{c}-1.141^{*} \\
(0.619)\end{array}$ & $\begin{array}{c}-0.133 \\
(1.571)\end{array}$ & $\begin{array}{r}-1.062 \\
(1.569)\end{array}$ & $\begin{array}{c}-2.618^{* * *} \\
(0.889)\end{array}$ & $\begin{array}{c}-1.320^{*} \\
(0.780)\end{array}$ \\
\hline$\alpha_{-4}$ & $\begin{array}{r}-0.457 \\
(0.294)\end{array}$ & $\begin{array}{r}-1.241 \\
(0.999)\end{array}$ & $\begin{array}{r}-0.636 \\
(0.643)\end{array}$ & $\begin{array}{c}-1.511^{* * *} \\
(0.523)\end{array}$ & $\begin{array}{r}-0.228 \\
(0.369)\end{array}$ & $\alpha_{13}$ & $\begin{array}{c}-1.663^{* * *} \\
(0.612)\end{array}$ & $\begin{array}{c}-0.092 \\
(1.499)\end{array}$ & $\begin{array}{c}-1.079 \\
(1.560)\end{array}$ & $\begin{array}{c}-2.603^{* * *} \\
(0.899)\end{array}$ & $\begin{array}{c}-1.699^{* *} \\
(0.679)\end{array}$ \\
\hline$\alpha-3$ & $\begin{array}{c}-0.623^{* *} \\
(0.315)\end{array}$ & $\begin{array}{r}-1.610 \\
(1.015)\end{array}$ & $\begin{array}{r}-0.972 \\
(0.670)\end{array}$ & $\begin{array}{c}-1.636^{* * *} \\
(0.526)\end{array}$ & $\begin{array}{c}-0.760^{* *} \\
(0.360)\end{array}$ & $\alpha_{14}$ & $\begin{array}{c}-1.717^{* * *} \\
(0.636)\end{array}$ & $\begin{array}{c}0.298 \\
(1.547)\end{array}$ & $\begin{array}{r}-1.131 \\
(1.600)\end{array}$ & $\begin{array}{c}-2.852^{* * *} \\
(0.907)\end{array}$ & $\begin{array}{c}-1.717^{* *} \\
(0.791)\end{array}$ \\
\hline$\alpha-2$ & $\begin{array}{c}-0.709^{* *} \\
(0.320)\end{array}$ & $\begin{array}{r}-1.502 \\
(1.023)\end{array}$ & $\begin{array}{r}-0.991 \\
(0.687)\end{array}$ & $\begin{array}{c}-1.993^{* * *} \\
(0.545)\end{array}$ & $\begin{array}{r}-0.497 \\
(0.393)\end{array}$ & $\alpha_{15}$ & $\begin{array}{c}-1.470^{* *} \\
(0.682)\end{array}$ & $\begin{array}{c}0.018 \\
(1.435)\end{array}$ & $\begin{array}{r}-1.152 \\
(1.614)\end{array}$ & $\begin{array}{c}-3.023^{* * *} \\
(0.966)\end{array}$ & $\begin{array}{c}-1.450^{*} \\
(0.753)\end{array}$ \\
\hline$\alpha_{-1}$ & $\begin{array}{r}-0.498 \\
(0.365)\end{array}$ & $\begin{array}{r}-1.432 \\
(1.018)\end{array}$ & $\begin{array}{r}-0.950 \\
(0.683)\end{array}$ & $\begin{array}{c}-1.863^{* * *} \\
(0.525)\end{array}$ & $\begin{array}{r}-0.180 \\
(0.444)\end{array}$ & $\alpha_{16}$ & $\begin{array}{c}-1.479^{* *} \\
(0.727)\end{array}$ & $\begin{array}{c}-0.117 \\
(1.458)\end{array}$ & $\begin{array}{r}-1.250 \\
(1.631)\end{array}$ & $\begin{array}{c}-3.227^{* * *} \\
(0.982)\end{array}$ & $\begin{array}{r}-0.739 \\
(0.696)\end{array}$ \\
\hline$\alpha_{0}$ & $\begin{array}{l}2.043^{* * *} \\
(0.377)\end{array}$ & $\begin{array}{l}2.656^{* * *} \\
(0.757)\end{array}$ & $\begin{array}{l}3.091^{* *} \\
(1.259)\end{array}$ & $\begin{array}{c}0.835 \\
(0.610)\end{array}$ & $\begin{array}{l}2.654^{* * *} \\
(0.533)\end{array}$ & $\alpha_{17}$ & $\begin{array}{c}-2.194^{* * *} \\
(0.664)\end{array}$ & $\begin{array}{c}-0.038 \\
(1.442)\end{array}$ & $\begin{array}{c}-1.064 \\
(1.840)\end{array}$ & $\begin{array}{c}-2.892^{* * *} \\
(0.944)\end{array}$ & $\begin{array}{c}-2.176^{* * *} \\
(0.780)\end{array}$ \\
\hline \multicolumn{7}{|c|}{ Lag cumulative sign-ups } & $\begin{array}{l}0.070^{* * *} \\
(0.020)\end{array}$ & $\begin{array}{c}0.027 \\
(0.054)\end{array}$ & $\begin{array}{l}0.064^{* *} \\
(0.031)\end{array}$ & $\begin{array}{l}0.069^{* * *} \\
(0.020)\end{array}$ & $\begin{array}{c}-0.055 \\
(0.042)\end{array}$ \\
\hline \multicolumn{7}{|c|}{ Lag cumulative sign-ups $*$} & $\begin{array}{r}-0.001 \\
(0.007)\end{array}$ & $\begin{array}{c}0.014 \\
(0.017)\end{array}$ & $\begin{array}{c}0.007 \\
(0.006)\end{array}$ & $\begin{array}{c}0.003 \\
(0.008)\end{array}$ & $\begin{array}{l}0.038^{* *} \\
(0.016)\end{array}$ \\
\hline \multicolumn{7}{|c|}{ Lag cumulative sign-ups $*$} & $\begin{array}{r}-0.003 \\
(0.011)\end{array}$ & $\begin{array}{c}0.007 \\
(0.026)\end{array}$ & $\begin{array}{r}-0.001 \\
(0.021)\end{array}$ & $\begin{array}{r}-0.009 \\
(0.010)\end{array}$ & $\begin{array}{l}0.065^{* *} \\
(0.029)\end{array}$ \\
\hline from 45 minutes to 90 minutes after threshold dummy $\left(\beta_{3}\right)$ & \multicolumn{6}{|c|}{ Lag cumulative sign-ups $*$} & $\begin{array}{r}-0.011 \\
(0.013)\end{array}$ & $\begin{array}{c}0.000 \\
(0.031)\end{array}$ & $\begin{array}{r}-0.010 \\
(0.019)\end{array}$ & $\begin{array}{r}-0.018 \\
(0.012)\end{array}$ & $\begin{array}{c}0.075^{* *} \\
(0.033)\end{array}$ \\
\hline Time & f-the-day fix & ed effects & & & & & Yes & Yes & Yes & Yes & Yes \\
\hline Deal & xed effects & & & & & & Yes & Yes & Yes & Yes & Yes \\
\hline Num & $r$ of observat & tions & & & & & 32,351 & 32,673 & 47,594 & 21,525 & 8,761 \\
\hline Num & $r$ of deals & & & & & & 953 & 962 & 1,401 & 634 & 258 \\
\hline
\end{tabular}

Note: Dependent variable is the number of new sign-ups per 5-min time interval. Standard errors are clustered by deal and reported in parentheses. ${ }^{* * *} p<0.01,{ }^{* *} p<0.05,{ }^{*} p<0.1$. 